\title{
Archaeological Survey of the Proposed Medina River Park, Bexar County, Texas
}

Antonia L. Figueroa

Center for Archeological Research, University of Texas at San Antonio

Steve A. Tomka

Raba Kistner

Follow this and additional works at: https://scholarworks.sfasu.edu/ita

Part of the American Material Culture Commons, Archaeological Anthropology Commons, Environmental Studies Commons, Other American Studies Commons, Other Arts and Humanities Commons, Other History of Art, Architecture, and Archaeology Commons, and the United States History Commons

Tell us how this article helped you.

This Article is brought to you for free and open access by the Center for Regional Heritage Research at SFA ScholarWorks. It has been accepted for inclusion in Index of Texas Archaeology: Open Access Gray Literature from the Lone Star State by an authorized editor of SFA ScholarWorks. For more information, please contact cdsscholarworks@sfasu.edu. 


\section{Archaeological Survey of the Proposed Medina River Park, Bexar County, Texas}

Creative Commons License

(c) (i) (8)

This work is licensed under a Creative Commons Attribution-NonCommercial 4.0 International License 


\section{ARCHAEOLOGICAL SURVEY OF THE PROPOSEd MEdINA RIVER PARK,}

BEXAR COUNTY, TEXAS

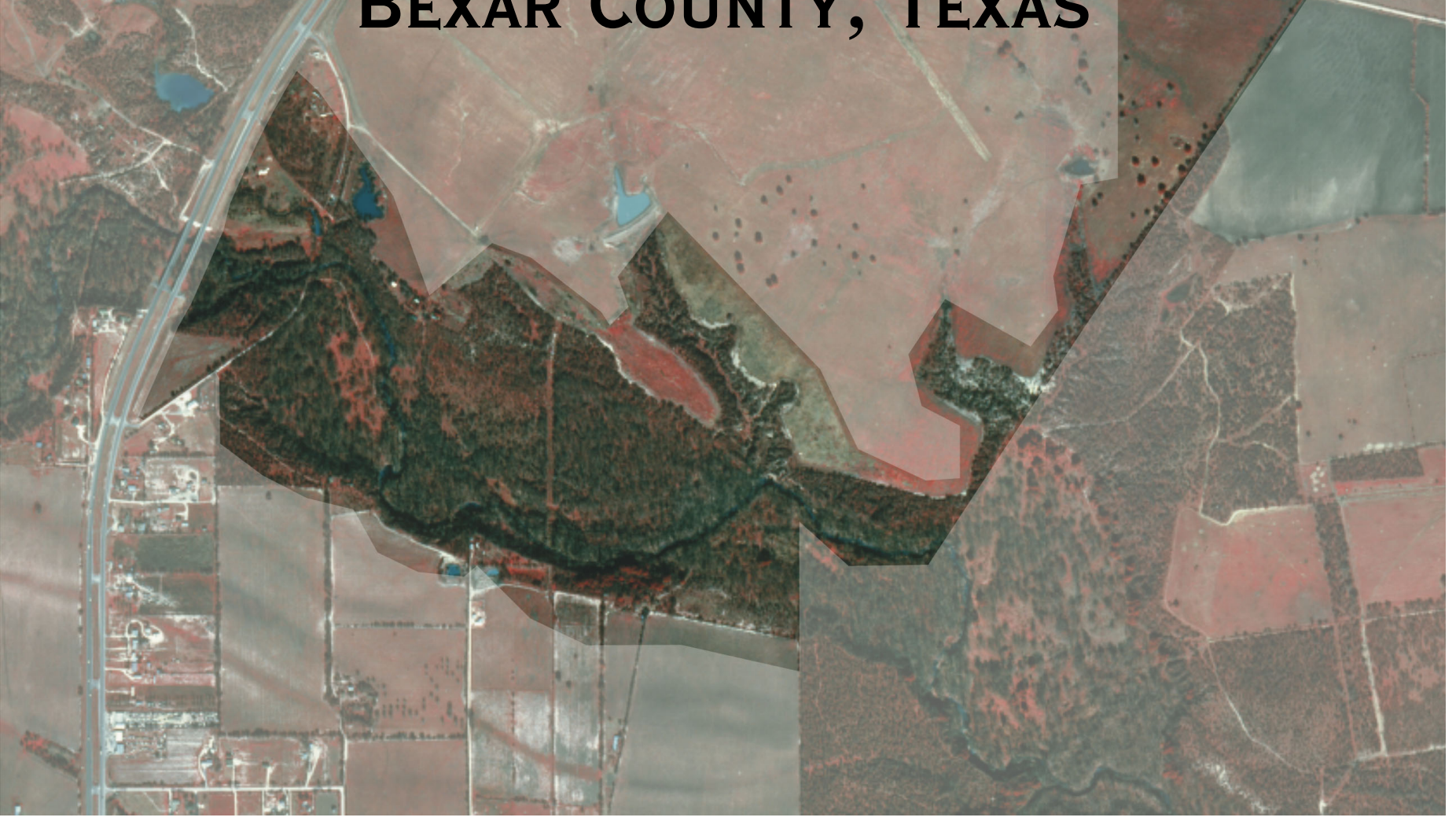

\section{Antonia L. FigueroA \\ AND}

\section{STEVE A. TOMKA}

PREPARED FOR:

CARTER \& BURGESS, INC.

911 Central Parkway, Suite 425

SAN ANTONIO, TEXAS
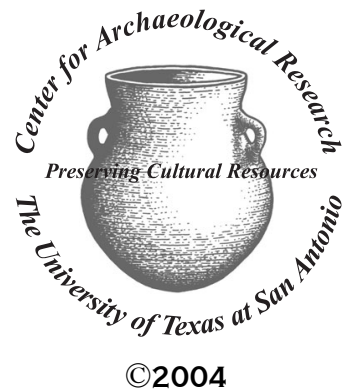

PREPARED BY:

CENTER for ARChaEological Research THE UNIVERsity OF TEXAS AT SAN ANTONIO ARCHAEOLOGICAL SURVEY REPORT, No. 345 


\title{
ARCHAEOLOGICAL SURVEY OF THE Proposed Medina River Park, BEXAR COUNTY, TEXAS
}

\author{
Antonia L. Figueroa and Steve A. Tomka
}

STEVE A. TOMKA

PRINCIPAL INVESTIGATOR

Texas Antiquities Permit No. 3163

PREPARED FOR:

CARTER \& BURGESS, INC.

911 CEnTRal Parkway, SUITE 425

SAn Antonio, TeXas

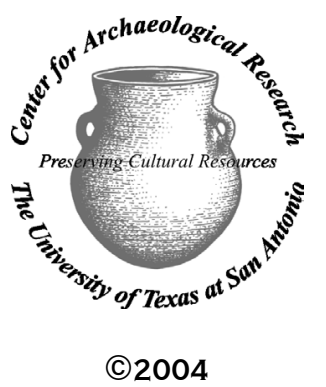

(C)2004
PREPARED BY:

Center for Archaeological Research THE UNIVERSITY OF TEXAS AT SAN ANTONIO ARCHAEOlogical SURVEY REPORT, No. 345 
A LiSt of PUblications offered by the Center for ARChaeological Research is aVAilable. Call (2 10) 458-4378; WRite to the Center for ARChaeological Research, THe University of TeXas at SAN Antonio, 6900 N. LoOP 1604 W., SAN ANTONIO, TEXAS 78249-0658; E-MAIL TO CAR@LONESTAR.UTSA.EDU; OR VISIT CAR'S WEB SITE AT HTTP://CAR.UTSA.EDU. 


\section{Abstract:}

From July to August 2003, the Center for Archaeological Research (CAR) at The University of Texas at San Antonio conducted an archaeological survey of the proposed 363-acre Medina River Park located in San Antonio, Bexar County, Texas. The 100 percent pedestrian survey was performed for Carter \& Burgess, Inc. on behalf of the San Antonio Parks and Recreation Department. The proposed park will consist of several hike and bike trails, roads, and parking facilities.

CAR staff revisited eight previously recorded sites, all of which were originally recorded between 1981 and 1984 during the Applewhite Reservoir survey (41BX346 [A \& B], 41BX347, 41BX348, 41BX350, 41BX519, 41BX675 [Thompson Cemetery], 41BX837, and 41BX857 [Palo Alto Crossing]). During the 2003 survey, four new sites were recorded by CAR (41BX1577, 41BX1578, 41BX1579, and 41BX1580).

One of the sites (41BX675) was determined to be eligible or potentially eligible for nomination to the National Register of Historic Places or for listing as a State Archeological Landmark. Site 41BX675 is the location of a cemetery identified during previous archaeological work, though no surface indications of graves were noted during the current survey. The National Register of Historic Places and State Archeological Landmark eligibility of site 41BX1577 remains unknown. CAR recommends the avoidance of disturbances to both sites. No further eligibility-related work is recommended on the remaining 10 sites. Nonetheless, given that some of the sites possessing high archaeological visibility may be subject to secondary impacts once the park is opened, a program of site management is proposed including systematic surface collections and the monitoring of collection and erosion impacts to surface-exposed archaeological materials.

All artifacts collected during these investigations are curated at the CAR facility according to Texas Historical Commission guidelines. These investigations were conducted under Texas Antiquities Permit No. 3163, with Dr. Steve A. Tomka serving as Principal Investigator. 


\section{Table of Contents:}

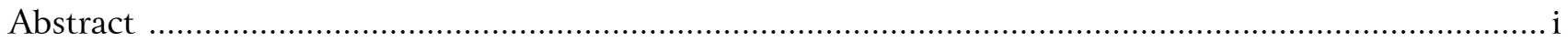

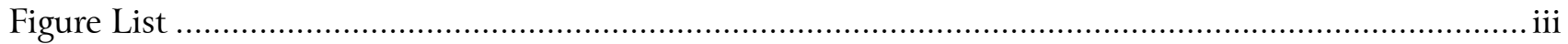

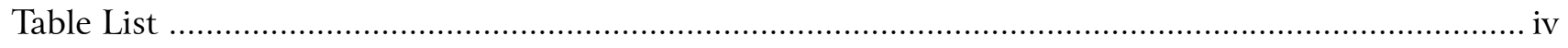

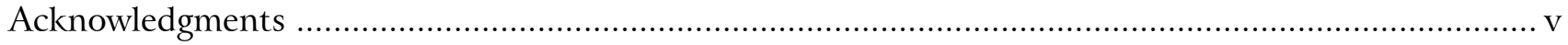

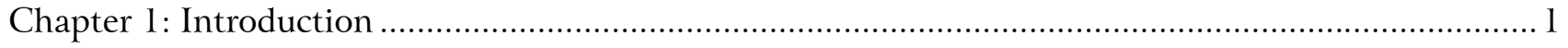

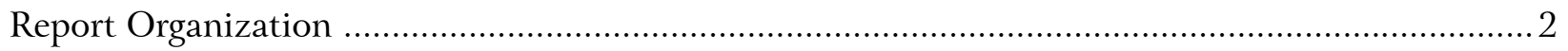

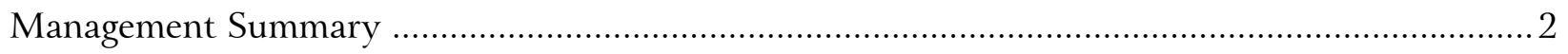

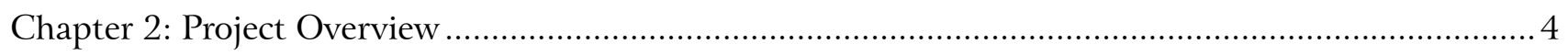

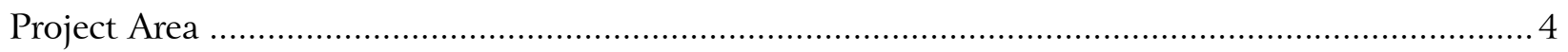

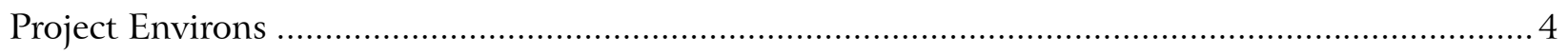

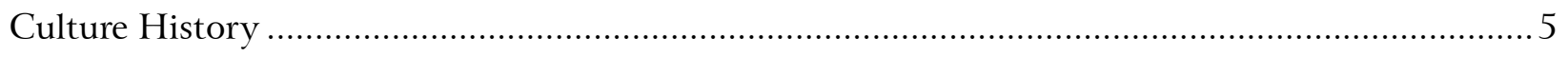

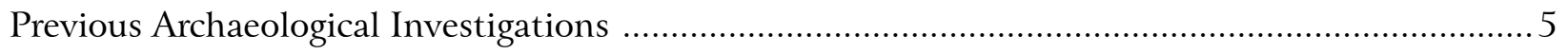

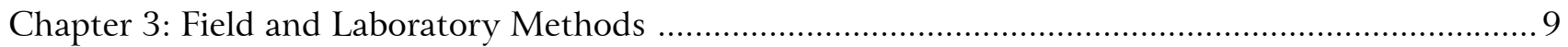

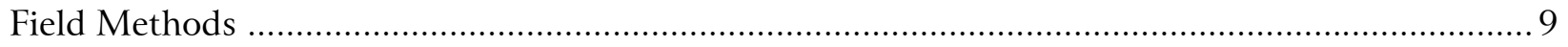

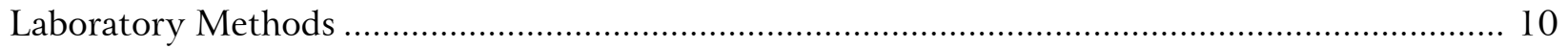

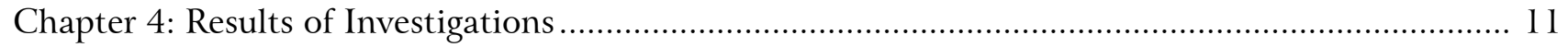

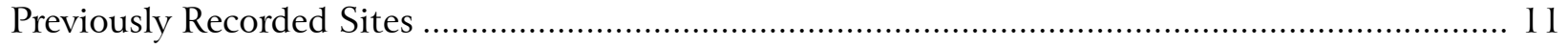

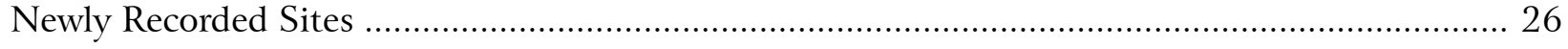

Chapter 5: Summary and Management Recommendations ....................................................... 35

Summary of Findings and Recommendations …............................................................... 35

Suggested Archaeological Properties Management Strategies .................................................. 37

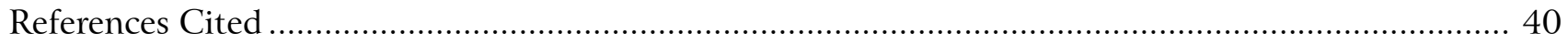




\section{Figures:}

Figure 1-1. Location of project area in southwest Bexar County. ................................................... 1

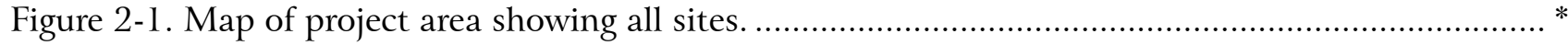

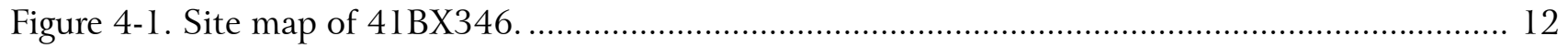

Figure 4-2. Backhoe Trench I south wall profile, 4IBX346..................................................... 13

Figure 4-3. Backhoe Trench 2 east wall profile, 41 BX346...................................................... 13

Figure 4-4. Backhoe Trench 3 west wall profile, 41BX346....................................................... 14

Figure 4-5. Backhoe Trench 4 west wall profile, 41BX346...................................................... 15

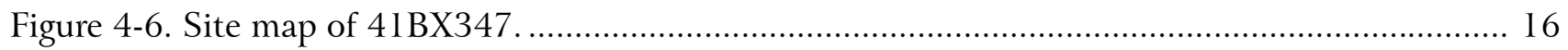

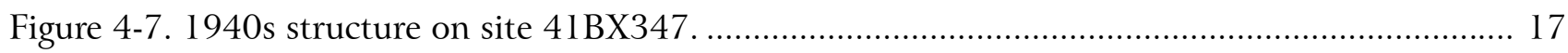

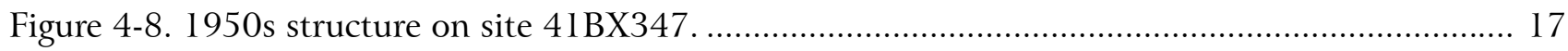

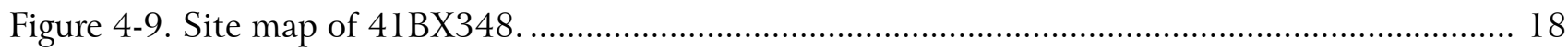

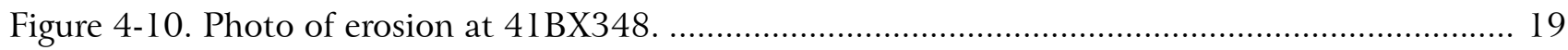

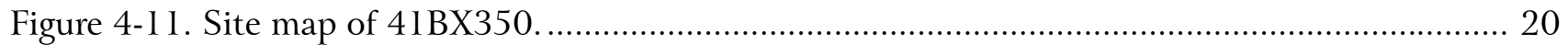

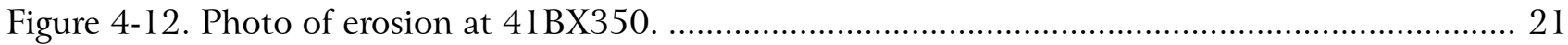

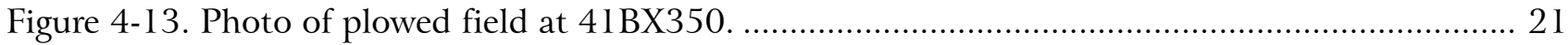

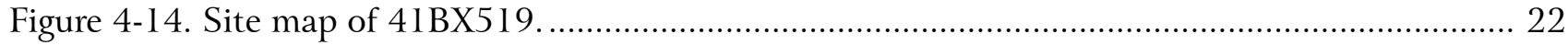

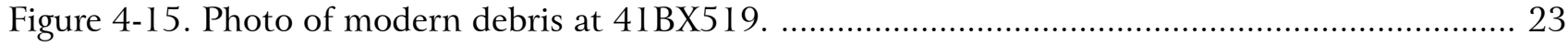

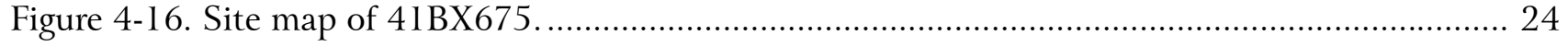

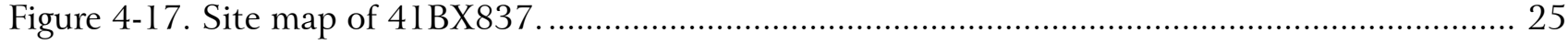

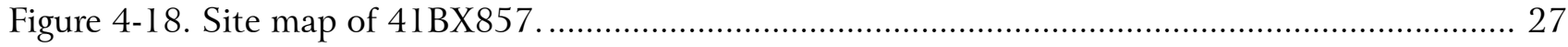

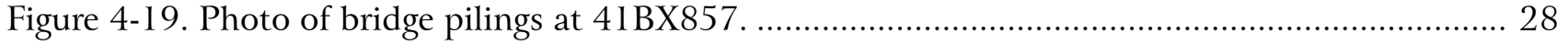

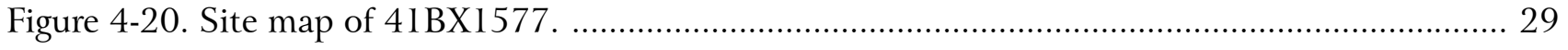

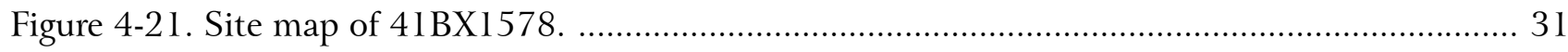

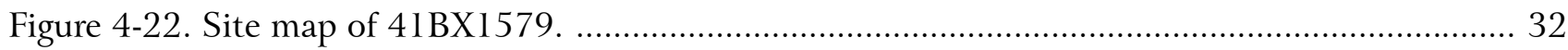

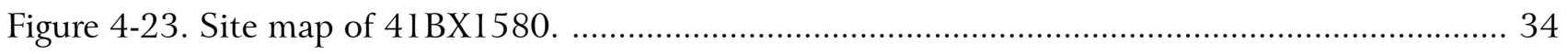

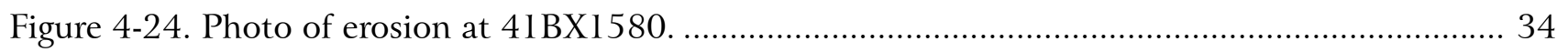

* Figure 2-1 is located in a pocket at the back of this report. 


\section{Tables:}

Table 4-1. Shovel Test Results from 41BX346 ......................................................................... 11

Table 4-2. Shovel Test Results from 41BX348 …................................................................... 19

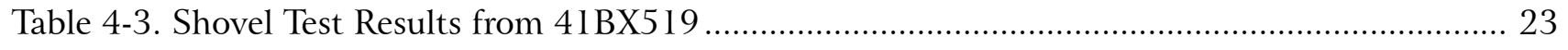

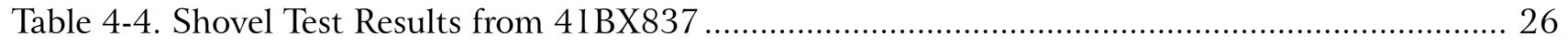

Table 4-5. Shovel Test Results from 41BX1577 ..................................................................... 30

Table 4-6. Shovel Test Results from 41BX1578 ............................................................................... 31

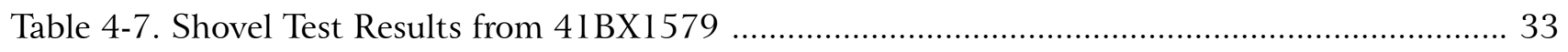

Table 5-1. Summary of Management Recommendations ............................................................ 36 


\section{Acknowledgments:}

The authors would like to thank Lisa Morris of the San Antonio Parks and Recreation Department and Kevin Conner of Carter \& Burgess, Inc. for their assistance. Dr. Steve Tomka, CAR Director, served as principal investigator on the project. Project archaeologists Richard Mahoney and Antonia Figueroa conducted field operations. The field crew consisted of Leonard Kemp, Bruce Moses, and Bryant Saner. Bruce Moses and Richard Young prepared the graphics for the project and the final report. Johanna Hunziker prepared the final report. Thanks also go out to Dr. Raymond Mauldin for his comments on the draft of this report. 



\section{Chapter 1: Introduction}

During July and August of 2003, the Center for Archaeological Research (CAR) of The University of Texas at San Antonio conducted a 100 percent pedestrian survey of the proposed 363-acre Medina River Park in south-central San Antonio, Bexar County, Texas (Figure 1-1). This cultural resource survey was conducted for Carter \& Burgess, Inc., hereafter the Client, on behalf of the San Antonio Parks and Recreation Department (SAPRD) in an effort to revisit and assess the current condition of previously documented sites and to identify any new cultural resources within the proposed park. The work was performed under Texas Antiquities Permit No. 3163, with Dr. Steve Tomka, CAR director, serving as Principal Investigator.
The proposed hike and bike trails and associated facilities (i.e., parking lots) will occupy a 3.6-mile-long rightof-way (ROW) on previously undeveloped land. Approximately 2.7 miles of the hike and bike trails will have to be newly developed. The entrance road and parking facilities will stretch for an additional 0.3 miles adjacent to State Highway 16. An additional 0.6 miles will run along existing dirt roads along the southwestern portion of the park.

The project area is within the boundaries of the formerly proposed Applewhite Reservoir, in south-central Bexar County. The area was investigated archaeologically during the 1980s and 1990s (Texas Historical Commission

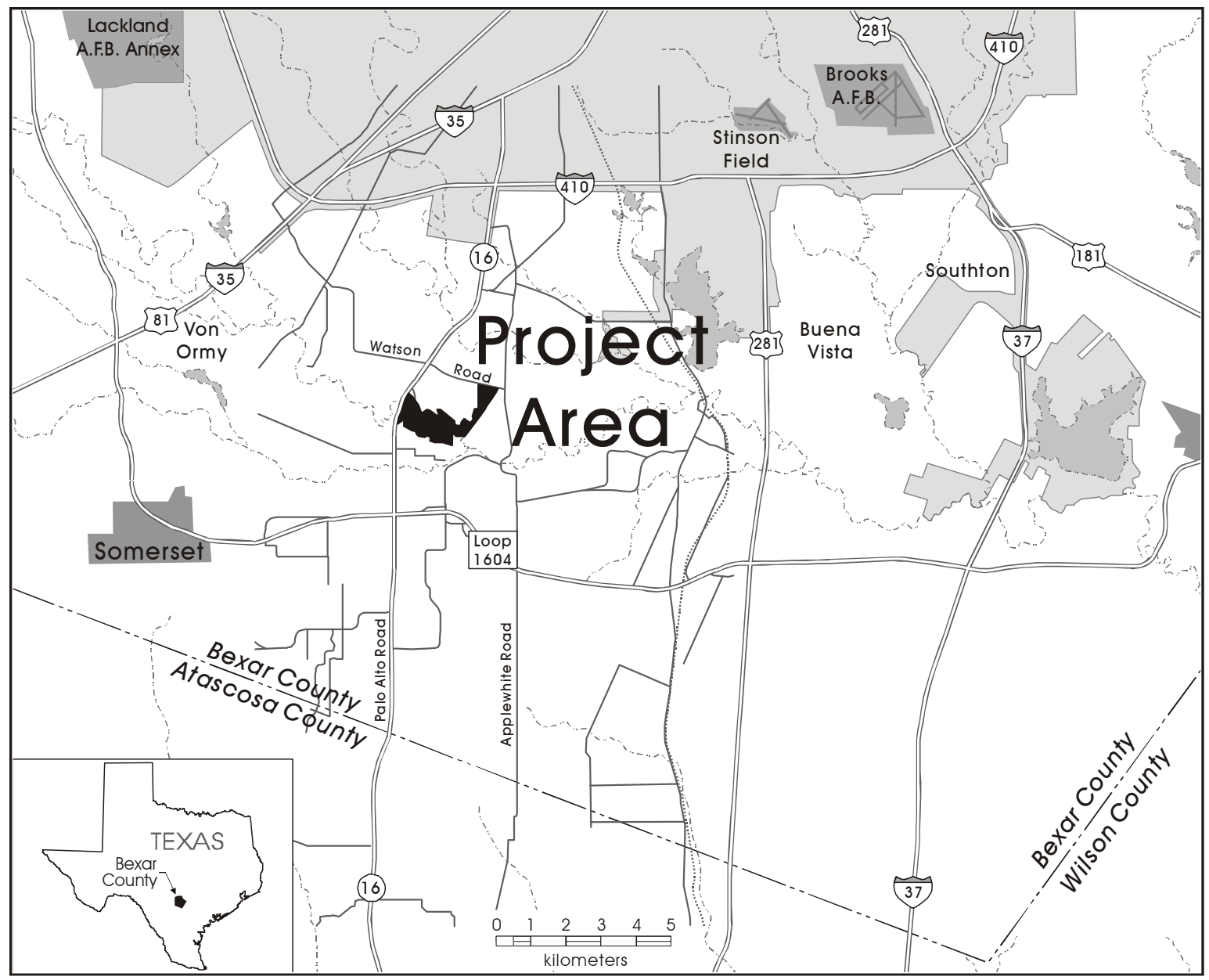

Figure 1-1. Location of project area in southwest Bexar County. 
[THC] 2003). Previously recorded archaeological sites that were revisited by CAR in 2003 were 41BX346A, 41BX346B, 41BX347, 41BX348, 41BX350, 41BX519, 41BX675, 41BX837, and 41BX857. Following the initial recording, sites $41 \mathrm{BX} 346 \mathrm{~A}$ and $41 \mathrm{BX} 346 \mathrm{~B}$ were combined into a single site. The subsequent discussion will refer to this property as a single site under the trinomial designation 41BX346.

In the process of conducting the 100 percent pedestrian survey of the proposed park, four new sites were identified and documented-41BX1577, 41BX1578, 41BX1579, and 41BX1580. Following the fieldwork and site revisits, CAR personnel, Kevin Conner of Carter \& Burgess, Lisa Morris of SAPRD, and Mark Denton of the Texas Historical Commission met regarding the outcome of the survey project. At this meeting it was requested that the northern boundary of one of the new sites (41BX1577) be marked off and this data be provided to the Client and the SAPRD to ensure that construction activities do not impact portions of the site that appear to contain research potential.

This report discusses the archaeological survey conducted by the Center for Archaeological Research for the Client (Carter \& Burgess, Inc.) and the SAPRD.

\section{Report Organization}

This report consists of five chapters. Following this introductory chapter, Chapter 2 provides an overview of the project area and summarizes the archaeological knowledge about the region. Fieldwork and laboratory methodology that was used for the project is reviewed in Chapter 3. Chapter 4 presents the results from the archaeological survey performed by CAR. Chapter 5 summarizes the work and provides recommendations for the sites.

\section{Management Summary}

The pedestrian survey of the proposed 363-acre Medina River Park in south-central Bexar County resulted in the reassessment of the National Register of Historic Places (NRHP) and State Archeological Landmark (SAL) eligibility of eight previously recorded sites and the documentation of four newly discovered sites. Based on the reassessment work conducted by CAR, it is recommend that only one of the eight previously recorded archaeological sites is eligible for nomination to the NRHP or for listing as a SAL. This site is 41BX675, the historic Thompson (Jett) Cemetery. Therefore, it is recommended that park developments avoid any direct impact to 41BX675 and its vicinity. Systematic monitoring of the site should be conducted to ensure that active erosion is not impacting buried remains. In addition, although no surface artifacts were noted at 41BX857, the historic Palo Alto Crossing of the Medina River, avoidance of major impacts to this locality is proposed in conjunction with the installation of signage highlighting the historic significance of the site. Avoidance of impact is proposed to help retain the historic visual integrity and context of the site.

None of the remaining six previously documented archaeological sites possess significant research potential. It is recommended that these sites are not eligible for nomination to the NRHP nor for listing as SALs. Therefore, no additional eligibility-related archaeological work is recommended at the following six previously recorded sites: 41BX346, 41BX347, 41BX348, 41BX350, 41BX519, and 41BX837. The construction of park facilities will directly impact three of these sites: 41BX346, 41BX347, and 41BX519. No immediate direct impacts are planned for the remaining three sites (41BX348, 41BX350, and 41BX837).

Although three of the four newly discovered and recorded archaeological sites possess moderate to high artifact densities, the heavy disturbance of these surface and shallowly buried deposits severely limits their research potential. Therefore, CAR recommends that these three sites, 41BX1578, 41BX1579, and 41BX1580, are not eligible for nomination to the NRHP nor for listing as SALs and no additional eligibility-related archaeological work is recommended at these newly documented sites.

Finally, 41BX1577 is a Late Prehistoric site with a surface exposed and shallowly buried Toyah component. The work conducted by CAR is insufficient at the present time to clearly determine the NRHP or SAL eligibility of the site. The construction of park-related facilities will not directly impact the site, although the parking facilities will directly abut its boundaries. It is recommended that Phase II archaeological testing be conducted if and 
when future developments of the park impact the site. The testing should focus on the determination of the site's NRHP/SAL eligibility. In the meantime, avoidance of disturbances and the systematic monitoring of the site and its contents are proposed as an immediate management strategy.

The majority of the sites within the proposed Medina River Park, such as 41BX348, 41BX350, 41BX675, 41BX837, 41BX1577, 41BX1578, 41BX1579, and 41BX1580, may not be impacted at all by direct construction. On the other hand, portions of other sites, such as 41BX346, 41BX347, 41BX519, and 41BX857 will be directly impacted by trail and support facilities construction. Regardless of direct impact from park development, the opening of the proposed park can have negative secondary impacts to all high surface visibility historic and prehistoric resources (i.e., abundant artifacts and standing structures) such as those present at 41BX347 (structures), 41BX519, 41BX1578 (historic and prehistoric artifacts), and 41BX1579 and 41BX1580 (prehistoric artifacts). A systematic program of site monitoring is proposed to document the impacts of park visitation on the historic and prehistoric resources of these sites. 


\section{Chapter 2: Project Overview}

This chapter describes the proposed Medina River Park and characterizes the project area environs and culture history. The chapter also summarizes the previous archaeological work conducted in the project area.

\section{Project Area}

The proposed Medina River Park will occupy 363 acres in south-central Bexar County. It is bound on the west by State Highway 16 (SH 16), on the northeast by Watson Road, and the Medina River to the south. It extends along both the northern and southern banks of the Medina River and also includes two small, unnamed intermittent creeks flowing into the Medina River from the north (Figure $2-1$, provided in pocket at back of report due to the sensitivity of site locations).

The northern entrance to the park will be some 0.2 miles north of the Medina River off SH 16. The proposed park and the Area of Potential Effects consist of a parking lot and pavilion adjacent to SH 16 in the northwest corner of the park property north of the river. A hike and bike trail will begin at this location and continue southeast along the Medina River forming a series of loops in the west-central portion of the proposed park. The proposed trail will not cross the Medina River. Rather, a separate section is planned for the south bank of the river entering the park approximately 0.4 miles south of the Medina River off SH 16. This portion of the hike and bike trail is to follow existing dirt roads with the exception of a 300400 foot section to be cleared in the vicinity of site 41BX519. A second pavilion and small parking area are planned between sites 41BX857 and 41BX519, at the end of an existing dirt road.

Within this Area of Potential Effects, the construction of the entrance road north of the Medina River will require extensive excavation and road grading to an estimated depth of 8 feet $(2.4 \mathrm{~m})$ and a width of some 45 feet (14 $\mathrm{m})$. Excavation and leveling in the area of the parking lot and pavilion is anticipated to disturb some 3-4 feet $(1-1.2 \mathrm{~m})$ below the present ground surface. The hike and bike trail leading from the parking lot to the beginning of the looped segments will consist of a concrete base. Its construction will necessitate excavation and grading to a depth of 6-8 inches $(15-20 \mathrm{~cm})$ below surface. The remainder of the trail system in the looped area will consist of a limestone base and its construction will not result in subsurface disturbances. The new segment of the hike and bike trail on the south side of the river will also consist of a limestone base and its construction will result in minimal, if any, subsurface disturbance. The remainder of the trail system will utilize existing roads and is not anticipated to result in any new subsurface disturbances. The width of the hike and bike trail will be approximately 10 feet $(3 \mathrm{~m})$ along its entire length.

\section{Project Environs}

The project area is entirely encompassed on the 1992 Terrell Wells 7.5 minute USGS quadrangle. Topographically, T2 and T3 terraces of the Medina River characterize the proposed park setting. Elevations in the project area range from 520 to 550 feet AMSL.

The project area is located south of the Edwards Plateau and below the Balcones Escarpment. Vegetation in the area consists of typical South Texas tree, scrub and grass species, including mesquite (Prosopis juliflora var. glandulos), live oak (Quercus virginiana), pecan (Carya illinoensis), Texas persimmon (Diospyros texana), prickly pear (Opuntia engelmannii), and greenbrair (Smilax rotundifolia; Vines 1960). The project area is primarily composed of soils that include Lewisville, Houston Black series, along with Hockley, Duval, Venus, Frio, and Webb Crockett series (Taylor et al. 1991). These soil types vary from clay and clay loam to sandy loam.

Climate in this general region is typically subtropical with cool winters and hot summers (Bomar 1995). Annual temperatures range from an average low of $57.7^{\circ} \mathrm{F}$ to an average high of $79.5^{\circ} \mathrm{F}$ (Bomar 1995). Rainfall averages about 30.98 inches a year (Bomar 1995). 


\section{Culture History}

Archaeological sites with long sequences of stratified deposits are relatively few in south-central Texas. Therefore, researchers working in the region often rely on the prehistoric sequence developed for Central Texas to frame the prehistory of South Texas. Researchers working in Central (Black 1986, 1989; Collins 1995; Prewitt 1981) and South Hester 1995) Texas have defined four major time periods: Paleoindian, Archaic (Early, Middle, Late), Late Prehistoric, and Historic. These periods are usually divided into sub-periods that are distinguished by particular subsistence strategies and material culture. A brief description of each of these time periods is provided here to illustrate the archaeological potential of the region.

\section{Paleoindian}

The Paleoindian period (11,500-8800 BP) is usually divided into early and late sub-periods, each marked by particular projectile point styles and subsistence patterns. Subsistence patterns varied from exploiting a diversity of flora and fauna to relying mainly on "big game" (Black and McGraw 1985:35), such as mastodon, mammoth and bison antiquus. Paleoindian-period materials are commonly found at kill, quarry, cache, camp, ritual and burial sites. Projectile points are often recovered as isolated finds (Collins 1995).

\section{Archaic}

During the Archaic period (8800-1200 BP) there was an intensification of hunting and gathering of local resources and a broader array of material culture. This period is also marked by an "extensive use of heated rock" (Collins 1995:383). Features such as hearths, ovens, and middens are seen increasingly at this point in time, marking a change in food processing (Black and McGraw 1985). The Archaic period spans thousands of years, showing that the adaptive strategies being employed were successful. The presence of large cemeteries signals perhaps the establishment of "territories" during this period (Black and McGraw 1985:38). The Early, Middle, and Late Archaic sub-periods are distinguished by differences in climate conditions, resource availability, subsistence practices, and diagnostic projectile point styles (Collins 1995).

\section{Late Prehistoric}

The appearance of arrow points and pottery marked the beginning of the Late Prehistoric period (1200-350 BP). This period is subdivided into early and late intervals termed Austin and Toyah Phases, respectively. The Austin Phase spans ca. 1200-650 BP (Prewitt 1981), and is marked by temporal diagnostics such as Scallorn and Edwards arrow points. The succeeding Toyah Phase consists of the final three centuries of the Late Prehistoric and includes the first occurrence of pottery in South Texas (Black 1986). Diagnostic projectile points of the Toyah Phase include Perdiz and Cliffton arrow points.

\section{Historic}

The beginning of the Historic period in South Texas is marked by the arrival of Europeans in the late seventeenth century. The northward expansion of Spanish influence and the southward push by the Comanche and later the Apache led to the displacement of many indigenous groups caught between these two forces. Others sought the protective environs of the numerous missions established in the early eighteenth century. Mission life influenced not only the beliefs and ways of life of huntergathers but also had a significant impact on their material culture. Artifact assemblages from this time reflect European influences (such as metal, glass and ceramics), but pre-Hispanic Goliad wares and lithic artifacts (arrow points, scrapers, gunflints) are also evident in the archaeological record.

\section{Previous Archaeological Investigations}

The project area is within the boundaries of the formerly proposed Applewhite Reservoir, an area of south-central Bexar County that has been subjected to extensive and systematic archaeological work from the 1980s through the 1990s. Archaeological investigations conducted by CAR during 1981 and 1984, in association with the proposed Applewhite Reservoir, identified and documented 85 sites (McGraw and Hindes 1987). The sites encountered vary in age from prehistoric to historic.

In the early 1990s, the Archaeological Research Program at Southern Methodist University (SMU) and the Center 
for Ecological Archaeology at Texas A\&M University (TAMU) performed limited survey and testing on several sites in the current project area (THC 2003). Investigations carried out by SMU and TAMU concentrated on the south bank of the Medina River and focused on both archaeological and paleoenvironmental studies. Eight archaeological sites identified during the Applewhite Reservoir surveys are located within the proposed Medina River Park area: 41BX346 (A \& B), 41BX347, 41BX348, 41BX350, 41BX519, 41BX675, 41BX837, and 41BX857.

\section{BX346 (41BX346A and 41BX346B)}

Site 41BX346 is crosscut by SH 16, with the majority of the site on the east side. It is located north of the Medina River, on its upper terraces, at an elevation of approximately 500-530 feet AMSL (Figure 2-1; McGraw and Hindes 1987:137-140). Originally, the site was recorded as consisting of two segments-41BX346A on the east side of the highway and 41BX346B encompassing the rest of the site. The two segments have been combined into one site for the purposes of this project.

At the time of its recording in 1981, an abandoned modern house and two outbuildings were recorded in the 41BX346A portion of the site. Previous investigations described the surface of the site as littered with burned limestone cobbles, reflecting the disturbed remains of prehistoric hearths, chipped lithic debris and lithic tool fragments (McGraw and Hindes 1987:137-140). The depth of the deposits was not ascertained although information from other sites located in similar settings along terraces of the Medina River suggested that materials could be buried in excess of 2-3 meters (6-9 feet) below the surface.

A revisit to the site in 1985 recorded extensive clearing of the terrace by bulldozing and subsequent erosion had severely disturbed the upper 1.5-3 meters of the deposits of the 41BX346A portion of the site. It was recommended, based on the previous investigations, that mechanical and hand excavations would be necessary to determine the research potential of the site and the significance of the deposits (McGraw and Hindes 1987:137-140).

\section{$41 \mathrm{BX} 347$}

This multicomponent (prehistoric/historic) site is located adjacent an abandoned historic ranch along an upper terrace on the left descending bank of the Medina River, approximately 750 meters east of SH 16 (Figure 2-1; McGraw and Hindes 1987:140). Previous investigations concluded that extensively disturbed cultural deposits were distributed across a 200 -meter by 300 -meter area of the terrace. Shovel testing indicated no cultural materials to a depth of $35 \mathrm{~cm}$ below surface, although deeper deposits were not tested. The surface materials consisted of burned rock and lithic debris, and no temporally diagnostic artifacts were noted on the surface.

While the surface materials of 41BX347 did not appear to have significant research potential during previous investigations, it was concluded that a comprehensive assessment of the site would require the removal and destruction of all structures in proximity to explore the potential for deeply buried deposits (McGraw and Hindes 1987:141).

\section{$41 \mathrm{BX} 348$}

This prehistoric site is located on the north terrace of the Medina River at its juncture with an arroyo complex that runs north-northwest from the Medina River (Figure 2-1; McGraw and Hindes 1987:142-143).

Previous investigations noted that the entire surface of the site was heavily eroded and deflated. Cultural materials observed on the surface included lithic debris and a low-density scatter of burned rock, no temporal diagnostic artifacts or cultural features were identified. No buried deposits were noted in the walls of any of the erosional gullies cross-cutting the site.

It was recommended in previous investigations that the cultural debris identified on surface had minimal research potential and that the site was not worthy of recommendation to the National Register of Historic Places. Nonetheless, in the absence of concrete evidence for significant buried cultural deposits, it was recommended that some monitoring may be necessary if future adverse impacts occurred on site (McGraw and Hindes 1987:143). 
Archaeological Survey of the Proposed Medina River Park

\section{$41 \mathrm{BX} 350$}

This prehistoric site is located at the confluence of a small arroyo and the Medina River on the left descending bank of the river and west bank of an arroyo (Figure 2-1). It is situated at an elevation of approximately 540 feet AMSL. In 1981 it was reported that a majority of the site surface has been subject to severe erosion (McGraw and Hindes 1987:143).

The cultural materials encountered on surface consisted of lithic debris and burned rocks. A single Leon Plain undecorated ceramic sherd, indicative of a Late Prehistoric occupation, was also collected "from a colluvial slope wash" (McGraw and Hindes 1987:144). No features were encountered. The inspection of the profiles of erosional gullies revealed no buried deposits (McGraw and Hindes 1987:143). No shovel tests were excavated during the initial recording of the site. Due to the low density of cultural materials, the lack of features, and the severe erosion of the site surface, the site was judged to have very limited research potential. Nonetheless, monitoring was suggested if and when future disturbances may impact deeper levels of the site where buried deposits may exist given the pattern at other sites within the Medina River Valley (McGraw and Hindes 1987:144).

\section{$41 B \times 519$}

Site 41BX519 is a historic site situated approximately 500 meters east of SH 16, on an upper terrace of the right descending bank of the Medina River at an elevation of approximately 520 feet AMSL (Figure 2-1). At the time of its initial recording, the site consisted of an abandoned single-story wood-framed house built during the latenineteenth or early-twentieth century (McGraw and Hindes 1987:149). In 1984, an inspection of deed records was not able to establish the ownership of the building; apparently, the structure was moved onto the property from a previous locality (McGraw and Hindes 1987:151). It was noted that the site was potentially eligible for listing on the National Register of Historic Places and further archival research would be necessary (McGraw and Hindes 1987:151).

\section{$41 \mathrm{BX} 675$}

This is the site of the Thompson Cemetery located immediately north of site 41BX837 (Figure 2-1). At one point, the cemetery was also known as the Jett Cemetery. The cemetery is known to contain at least two burials. One was marked by a headstone and footstone at the time of the initial site recording. The headstone identified the deceased as "Louisiana J. wife of H. L. Thompson: born Sept 25, 1818, died Jan. 27, 1863" (McGraw and Hindes 1987:255).

A metal fence was said to have surrounded the second grave. Oral history interviews have revealed that at least two children may also have been buried at the site. Since the site could not be visited at the time its assessment was being prepared, a site visit was recommended to establish its current status when access to the property was attained (McGraw and Hindes 1987:255). In 1990 there was an on-site inspection of 41BX675 by TAMU and SMU but no excavations were conducted (THC 2003). There was an on-site observation of a grave and further archival research was recommended (THC 2003).

\section{$41 \mathrm{BX} 837$}

Site 41BX837 is a large ( $300 \mathrm{~m} \times 75 \mathrm{~m})$ multicomponent site located on a high terrace along the right descending bank of the Medina River (Figure 2-1). Archaeological survey conducted by TAMU staff indicated the presence of ironstone, window glass, cut nails, transfer ware and whiteware ceramics on surface (THC 2003). All standing structures at the time of the 1989 survey appeared to be of post-1950s construction but the pre-1900s material remains were suggestive of a shallowly buried historic component that pre-dates the structures. The historic Thompson Cemetery (41BX675) is located immediately north of the site, at the edge of the terrace. A headstone inspected at the time of the survey bore early- to midnineteenth-century dates (1818-1863). It is possible that the historic component dates to this period.

The prehistoric remains on surface consisted of end scrapers, unmodified flakes, mussel shell, and angular burned rocks. The presence of end scrapers may be 
indicative of a Late Prehistoric component; however, other work in the Applewhite Reservoir has documented that the upper terrace where the site sits contains deeply buried (2.5-3.0 m deep) archaeological remains at a number of other localities (Thoms et al. 1996). Therefore, it is possible that such deeply buried material may also underlie this locality.

\section{$41 \mathrm{~B} \times 857$}

This site is the location of the Palo Alto Crossing of the Medina River (Figure 2-1). It was recorded by SMU and TAMU in 1990 (THC 2003). The crossing was identified by Melchor de la Garza as Paso Sabinitas and was called Jett crossing by the mid-1860s, named after the Jett Family that lived on the south bank of the river (Hindes 2003:39). The bridge that spanned the stream had collapsed sometime between the 1930s and 1950s, although some structural remnants were still present in 1990 at the time of the TAMU survey. A rich mixture of Colonial and nineteenth-century materials littered the surface of the site at the time of its recording. The ceramics included lead-glazed and tin-glazed majolica, native Goliad ware, flowblue, spongeware, stoneware and ironstone. Also included in the artifacts was olive bottle glass and pressed glass.

The remains indicated the lengthy use of the area perhaps going back into prehistoric times or at least to the protohistoric (native and Spanish contact period) as suggested by the Goliad pottery. The materials were concentrated on the south bank of the river, and it was not ascertained whether debris was present on the north bank (THC 2003). 


\section{Chapter 3: Field and Laboratory Methods}

As part of the archaeological services provided the Client, and in accordance with the Texas Historical Commission guidelines, the Center for Archaeological Research was contracted to conduct the following fieldwork: 1) survey the proposed park and hike and bike trails and associated facilities to ascertain whether any hitherto undocumented cultural resources would be adversely impacted by the proposed development; 2) reassessment of previously recorded sites within the project area; and 3) backhoe trenching on that portion of site 41BX346 which will be impacted by grading for facilities construction.

\section{Field Methods}

When investigating non-site areas, the CAR field crew traversed the project area along 30-meter transects. Aerial photographs with clearly marked transects and hand-held compasses were used to orient crewmembers. Portions of the project area were divided into smaller adjoining segments that aided in orientation and access to the property. In non-site areas, shovel tests were spaced such that consistent coverage was achieved within the survey area. However, shovel test coverage was increased in areas that were considered preferred for prehistoric and/ or historic habitation (i.e., high probability areas such as interfluves overlooking confluence of streams, terraces overlooking streams, raw material outcrops) and were not previously impacted by heavy surface erosion. This shovel testing strategy meant that in upland areas where the probability of buried deposits may be low, shovel test densities were reduced, while in high probability settings, the density of shovel tests was increased. Shovel tests were $30 \mathrm{~cm}$ in diameter and excavated to a maximum depth of $60 \mathrm{~cm}$ below surface, unless otherwise prevented from reaching this depth. The shovel tests were excavated in levels that did not exceed $10 \mathrm{~cm}$ in thickness. Deposits from these tests were screened through $1 / 4$-inch mesh, all artifacts were collected and observations from the shovel tests were recorded on standardized forms. All artifacts recovered from shovel tests were returned to the CAR laboratory for processing and curation.
For the purpose of this survey, newly encountered sites were defined as locations having at least five artifacts within a $30 \mathrm{~m}^{2}$ area, or as a location containing a single cultural feature such as a hearth. All other artifacts were classified as isolated occurrences. When new surface sites were encountered during survey shovel testing, shovel tests were excavated within the vicinity of the surface scatter of materials that defined the extent of the distribution. When an artifact concentration was identified as a site, crewmembers established a datum consisting of a length of rebar hammered into the ground at the site's center. Hand-held Global Positioning System (GPS) units were used to map each site. Standardized forms containing observations concerning site disturbance, vegetation, artifacts, and observations on features were completed. In addition, sketch maps showing site boundaries, datum locations, shovel tests, collected items, features, areas of high artifact density, and physical features on the landscape were drawn. Archival quality prints were made of all sites and artifacts when appropriate. Texas site forms were prepared for all newly documented and revisited sites on the project.

To reassess the eight previously recorded archaeological sites within the bounds of the proposed park, CAR archaeologists relocated each site using aerial photographs and field maps showing the location and outline of the sites as defined during the original survey. Once a site was relocated, crewmembers made written observations regarding the types of cultural materials noted on surface, the relative density of materials, presence/absence of artifact clusters, and temporal diagnostics. Five to nine shovel tests were excavated on all revisited sites to establish the depth of cultural materials. Only diagnostic artifacts were collected from the surface, and their location recorded with a GPS unit. All diagnostic artifacts collected from the surface and all artifacts recovered in shovel tests were returned to the CAR laboratory for processing and curation.

To determine whether significant cultural materials were present and would potentially be impacted by the construction of the park entrance road on site 41BX346, 
a CAR archaeologist monitored the excavation of four backhoe trenches along the northern portion of the site, within the proposed ROW of the entrance road and parking lot. Backhoe trenches were excavated in accordance with the THC archaeological survey standards as one meter wide and at least five meters long. Trenches did not exceed 1.5 meters in depth to maintain safe working conditions. Approximately three-meter-long representative sections of each backhoe trench were profiled and described. No matrix was screened from the backhoe trenches.

\section{Laboratory Methods}

All cultural material collected during the survey was prepared in accordance with federal regulation 36 CFR part 79, and in accordance with current guidelines of the Center for Archaeological Research. Artifacts processed in the CAR laboratory were washed, air-dried, and stored in archival-quality bags. Artifacts were sorted into appropriate analytical categories (e.g., debitage, projectile points, bifaces, unifaces, cores, ceramics, etc.). All artifacts were given a specific catalog number and then entered into an Excel $^{\circledR}$ spreadsheet. Acid-free labels were placed in all artifact bags. Each label contains a provenience or corresponding lot number. Lithic tools were labeled with permanent ink and covered by a clear coat of acrylic. In addition, a small sample of unmodified flakes from each lot was labeled with the appropriate provenience data. Artifacts were separated by class and stored in acid-free boxes. Boxes were labeled with standard labels.

Field notes, forms, photographs, and drawings were placed in labeled notebooks. Photographs and negatives were placed in archival-quality sleeves. All notebooks are stored in acid-free folders. Documents and forms were printed on acid-free paper. A copy of the survey report and all computer disks pertaining to the investigations are stored in an archival folder and curated with the field notes and documents. Upon completion of the project, all cultural materials and records were curated at the CAR facility. 


\section{Chapter 4: Results of Investigations}

The fieldwork for the proposed Medina River Park was completed in two phases. The first phase spanned from July 8 through July 18, 2003, under the direction of Project Archaeologist Richard Mahoney. This first phase of the survey consisted of the pedestrian survey of approximately 295 acres of the 363 -acre proposed park area, predominantly in the western portion of the project area. Six out of the eight previously recorded sites were relocated and reassessed. Additionally, three new sites were encountered (41BX1577, 41BX1578, and 41BX1579). Backhoe trenching was also carried out in the northern portion of 41BX346. The second phase of fieldwork concentrated on the investigation of the eastern portion of the project area and was conducted on August 5-8, 2003, and August 21, 2003, with Antonia Figueroa serving as Project Archaeologist. This phase consisted of investigating the remaining acreage (approximately 68 acres) and revisiting and reassessing two previously recorded sites (41BX348 and 41BX350). Site 41BX1580 was identified and recorded at this time.

In the following discussion, the results of investigations of the revisited sites are presented first, followed by the newly recorded sites.

\section{Previously Recorded Sites}

During July and August 2003, using aerial photographs and field maps showing the locations and outlines of the sites as defined during the original surveys, the eight known archaeological sites in the project area were relocated. There were instances when little or no cultural material was encountered on surface or subsurface. In these instances topography, i.e., setting or surrounding landmarks, was the main feature used to relocate the sites.

\section{$41 B \times 346$}

Proposed developments in this portion of the park include parking facilities and a road impacting mainly the northern and eastern portions of the site (Figure 4-1). During the 2003 site revisit the crew noted that erosion resulting from land disturbances during the 1980s has severely impacted the site. Prehistoric materials (firecracked rock [FCR], one core, one tested cobble, and one flake) and modern debris (asphalt, ceramic tile, window glass, concrete, and terra cotta pipe) were encountered mixed in an erosional gully. It appears that the modern materials represent the trash dump of the contemporary house just north of the site. Seven shovel tests were placed in this site area (Table 4-1). Shovel tests revealed that the soils consist of yellowish brown silty loam, which contains gravels within the first $10 \mathrm{~cm}$ below surface (cmbs). Of the seven shovel tests excavated on site, two were positive. Shovel Test (ST) L7 contained one historic ceramic sherd in Level 2 (10 $20 \mathrm{cmbs}$ ) and ST L8 contained one piece of debitage in Level 4 (30-40 cmbs).

Four backhoe trenches also were placed along the northeastern perimeter of 41BX346 in the proposed ROW of the entrance road and parking lot. No cultural material was identified in the backhoe trench profiles or in the backdirt that was visually inspected as it was dumped in the vicinity of the trenches. Backhoe Trench 1 (BHT 1) was oriented northwest-southeast. The south wall of BHT 1 was profiled (Figure 4-2). The brown

Table 4-1. Shovel Test Results from 41BX346

\begin{tabular}{|l|c|c|c|c|}
\hline Shovel Test No. & Max. Depth (cmbs) & Artifact & Count & Level of Artifact (cmbs) \\
\hline R8 & 20 & 0 & 0 & 0 \\
\hline R9 & 60 & 0 & 0 & 0 \\
\hline BKM3 & 40 & 0 & 0 & 0 \\
\hline BKM4 & 60 & 0 & 0 & 0 \\
\hline L7 & 60 & White earthern ware & 1 & $2(10-20)$ \\
\hline L8 & 60 & Debitage & 1 & $4(30-40)$ \\
\hline B7 & 60 & 0 & 0 & 0 \\
\hline
\end{tabular}




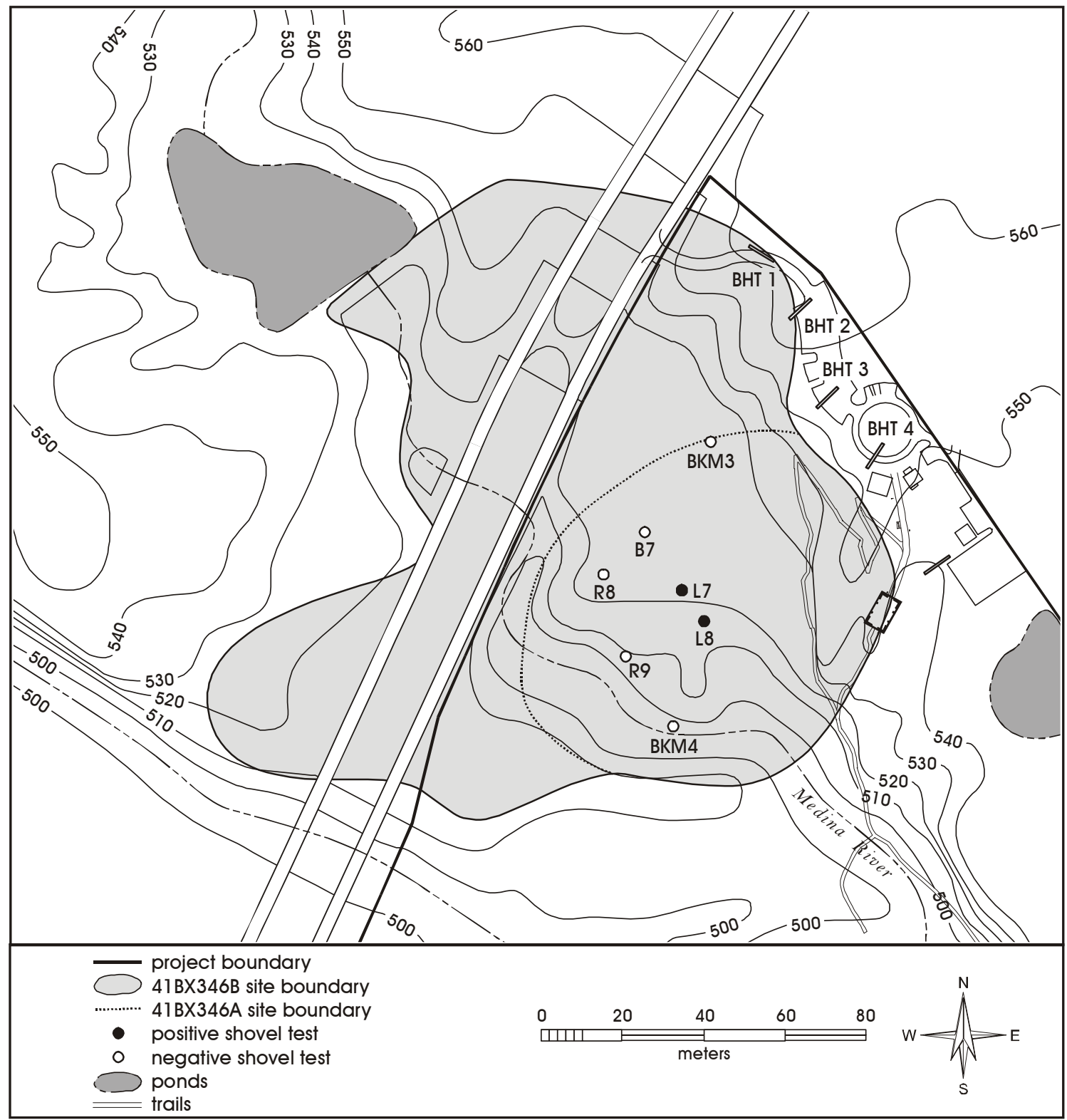

Figure 4-1. Site map of $41 B X 346$.

topsoil in BHT 1 extended from 1-5 $\mathrm{cm}$ below surface. From approximately 5-10 cmbs the soil was brown sandy loam. Soils from 10-70 cmbs consisted of light brown sandy loam with a charcoal inclusion. From $70-80 \mathrm{cmbs}$ the soil was tan sandy clay with sandstone inclusions. The remainder of the profile $(80-140 \mathrm{cmbs})$ was gray clay mottled with yellow.

Backhoe Trench 2 (BHT 2) was oriented northeastsouthwest. The east wall of the trench was profiled
(Figure 4-3). The top $3 \mathrm{~cm}$ consisted of brown sandy loam. Between 3-40 cmbs the soil was dark brown sandy loam with calcium carbonate inclusions. The remainder of the profile (40-100 cmbs) was light gray clay with yellow mottling.

Backhoe Trench 3 (BHT 3) was orientated northeastsouthwest and contained a significant amount of sandstone. The west wall of the trench was profiled (Figure 4-4). The humus layer of BHT 3 was only 


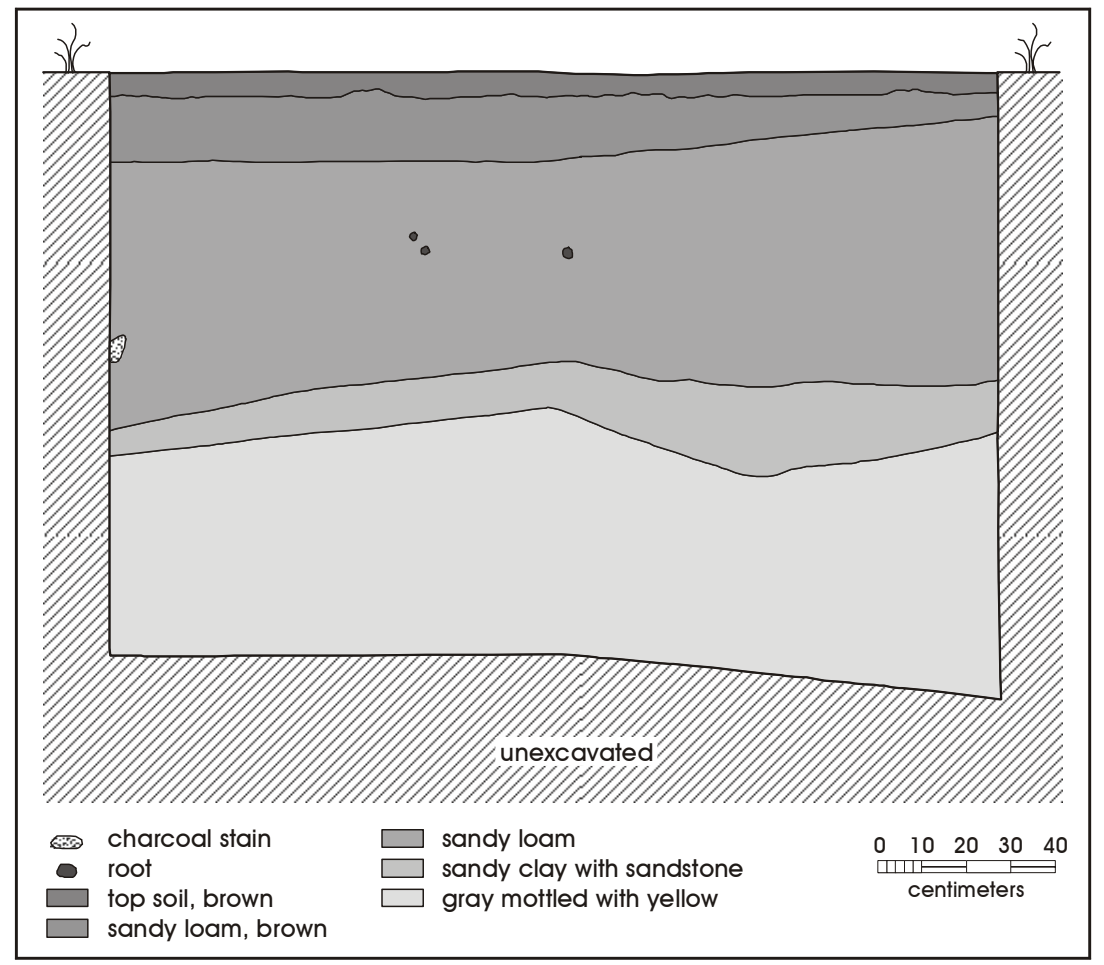

Figure 4-2. Backhoe Trench 1 south wall profile, 41BX346.

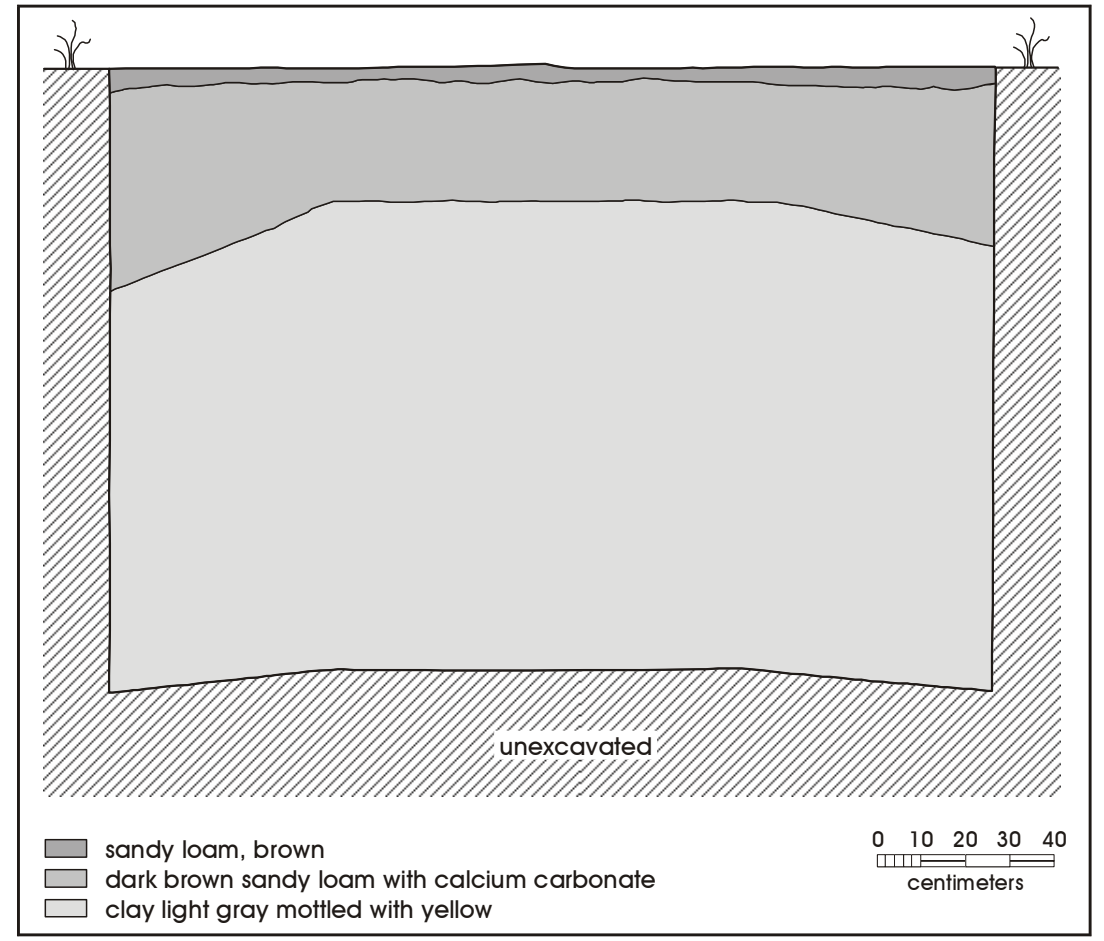

Figure 4-3. Backhoe Trench 2 east wall profile, 41BX346. 


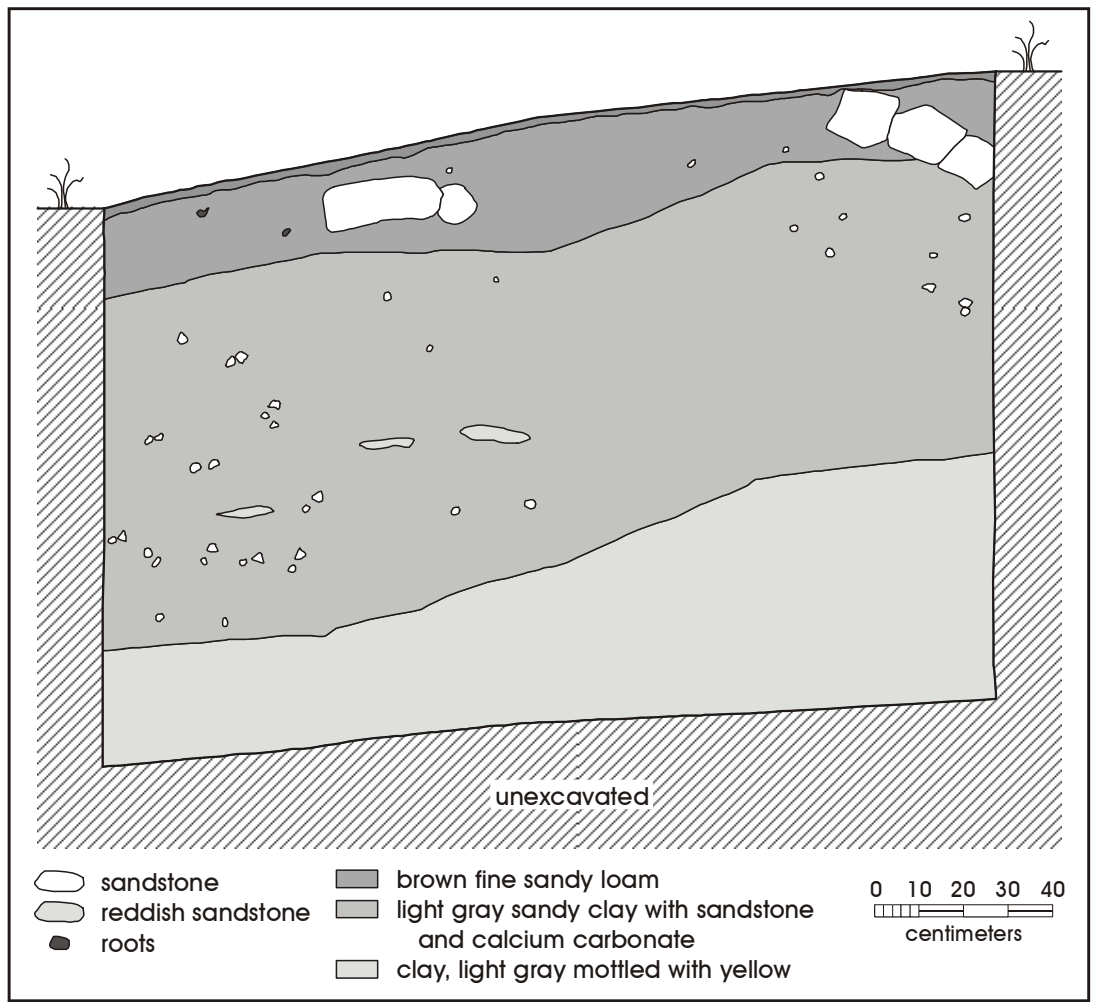

Figure 4-4. Backhoe Trench 3 west wall profile, 41 BX346.

approximately $2-3 \mathrm{~cm}$ thick. Brown fine sandy loam with sandstone inclusions occurred from 3-15 cmbs. From $15-65 \mathrm{cmbs}$ the soils consisted of light gray sandy clay with sandstone and calcium carbonate inclusions. The remainder of the profile $(65-120 \mathrm{cmbs})$ consisted of light gray clay with yellow mottling.

Backhoe Trench 4 (BHT 4) was orientated northeastsouthwest. The west wall of BHT 4 was profiled (Figure 4-5). The top 13-26 cm of BHT 4 consisted of dark brown loose sandy loam, with a few sandstone inclusions. From 26-65 cmbs the soils consisted of dark brown sandy loam with a 5-10-cm-thick sandstone lens. The bottom $40-78 \mathrm{cmbs}$ was dark gray clay mottled with tan with a 3 -cm-thick sandstone lens in the upper $5 \mathrm{~cm}$ of the profile.

Low densities of both prehistoric and historic materials were noted on surface; however, due to the highly disturbed nature of the deposits, the site possesses minimal research potential.

\section{$41 \mathrm{BX} 347$}

Proposed park developments consist of trail segments across the southeastern portion of site 41BX347 (Figure 4-6). The majority of this site is now open, plowed field and no surface expression was evident at the time of the revisit, even with nearly 100 percent surface visibility. Seven shovel tests were excavated during the revisitall were negative. Any material evident during the 1980s could have been removed by erosion of the site. Shovel tests revealed that soil in this area varies from yellowish brown silty loam to dark brown clay loam. The two historic structures at the site were photographed and inspected for NRHP eligibility. One of the structures may date as early as the 1940s (Figure 4-7), and the second structure probably dates to the early 1950s (Figure 4-8). Though the first structure appears on the 1942 Terrell Wells quadrangle map, neither is shown on the 1903 quadrangle. Both structures have been substantially modified with additions built after the 1950s. 


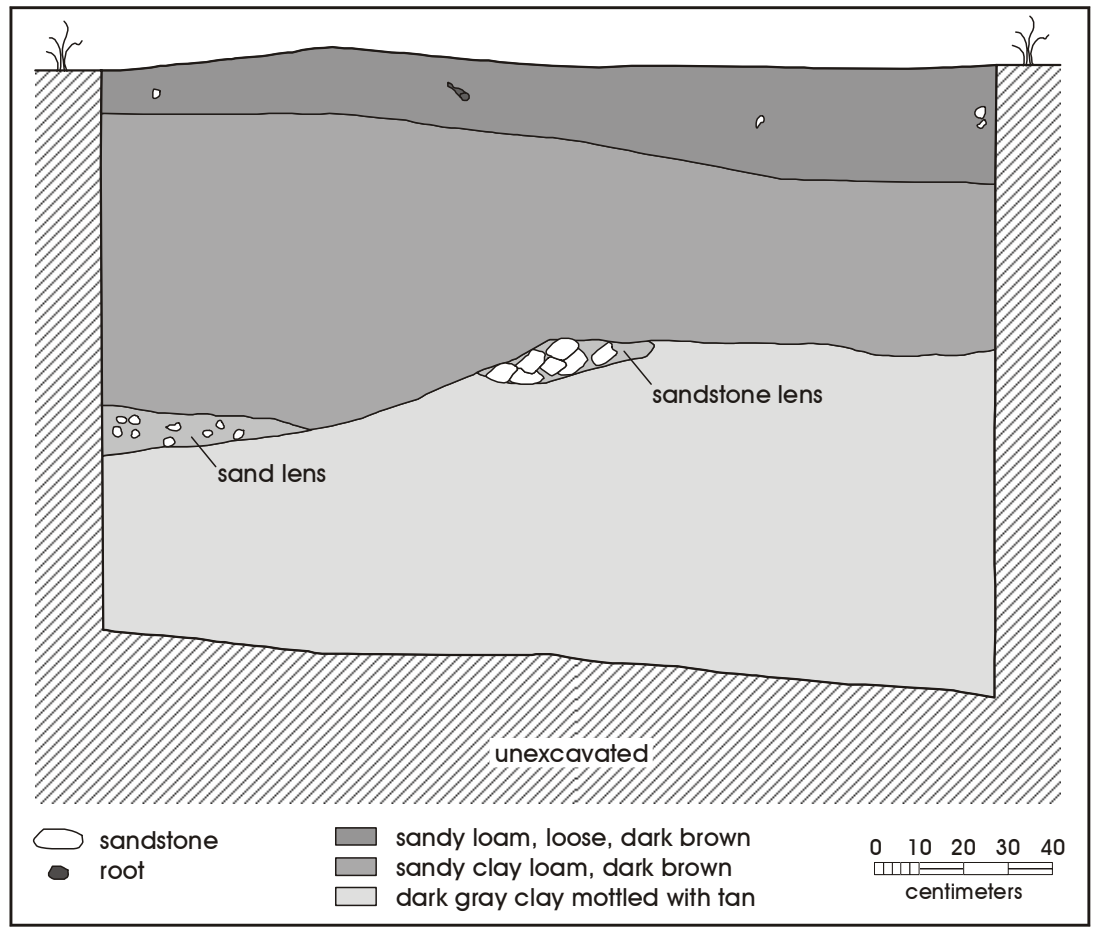

Figure 4-5. Backhoe Trench 4 west wall profile, 41 BX346.

\section{$41 \mathrm{BX} 348$}

The proposed park developments do not directly impact this site area (Figure 4-9). The western and southern portions of the site are sparsely wooded and heavily eroded by several crosscutting drainages (Figure 4-10). The eastern side of the site consists of an open, plowed area. Eleven shovel tests were excavated during the site revisit. Only one shovel test was positive (ST B34). One flake each was encountered in Level $1(0-10 \mathrm{cmbs})$ and Level 4 (30-40 cmbs) of the shovel test (Table 4-2). One core was noted on the surface near ST T5, but was not collected. Soils in the shovel tests consisted of dark brown clay loam to reddish brown silty loam, with calcium carbonate inclusions. During inspection of the eroding drainages, no cultural material was noted. No buried deposits were noted during the original work and it is likely that the buried materials from ST B34 are in secondary context. Given the extensive disturbance of the site, and the small quantity of cultural deposits in likely secondary context, it is suggested that the site has very low research potential.

\section{$41 \mathrm{BX} 350$}

No park development will directly impact this portion of the project area (Figure 4-11). The eastern half of the site is badly eroded, while the western half is open pasture (Figures 4-12 and 4-13). Six shovel tests were excavated across the western and central portions of the site; all were negative. A single core was encountered on the surface near ST L40, but was not collected. Based on the shovel tests, soils in the area are brown and grayish silty clay loam. Several of the eroding drainages were inspected during the revisit and no cultural material was identified. Due to the fact that approximately 75 percent of the site is eroded, in combination with the low density of surface artifacts and the lack of buried deposits at least to the tested depth, it appears that the site has little research potential. 


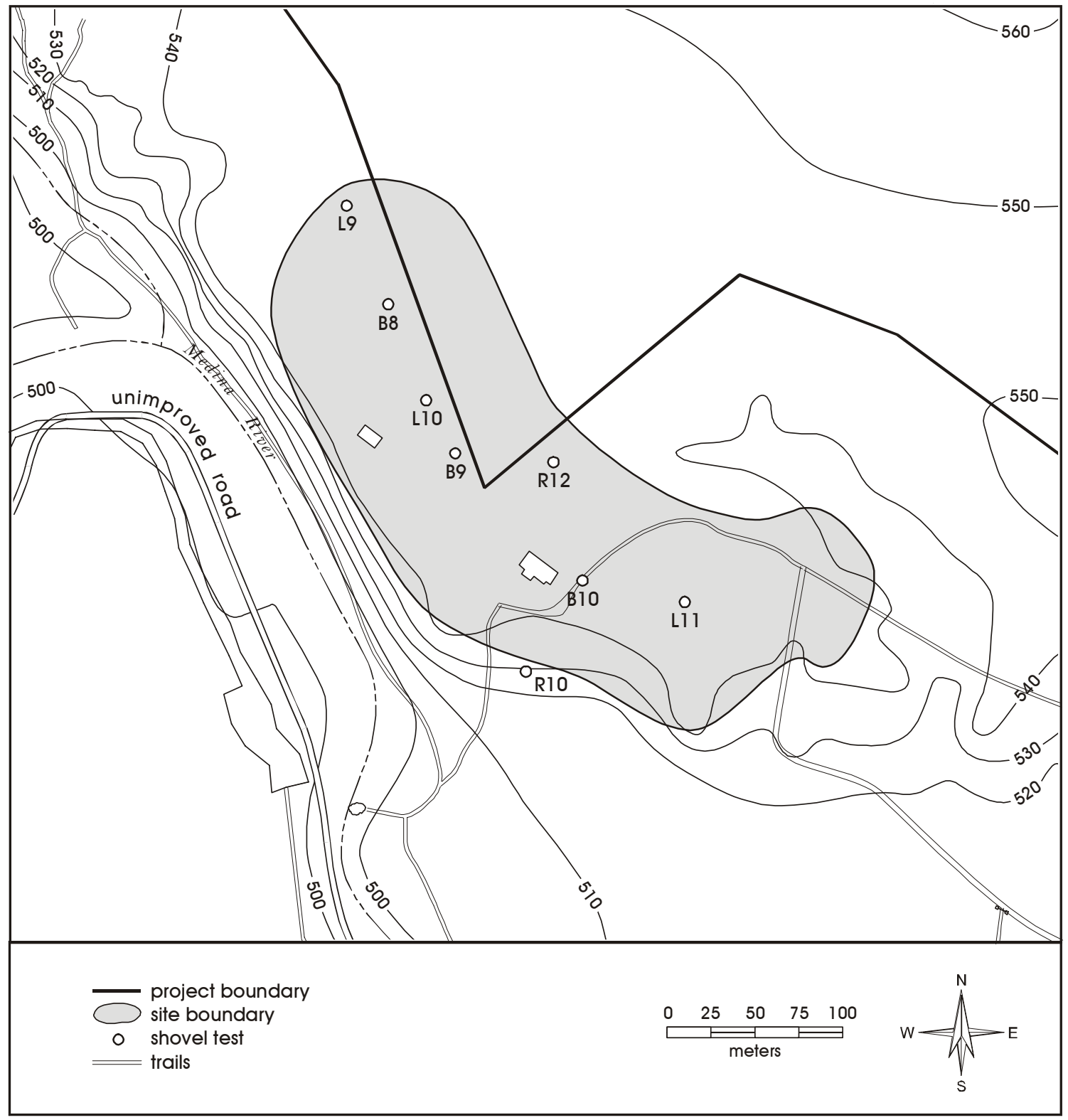

Figure 4-6. Site map of $41 B X 347$. 


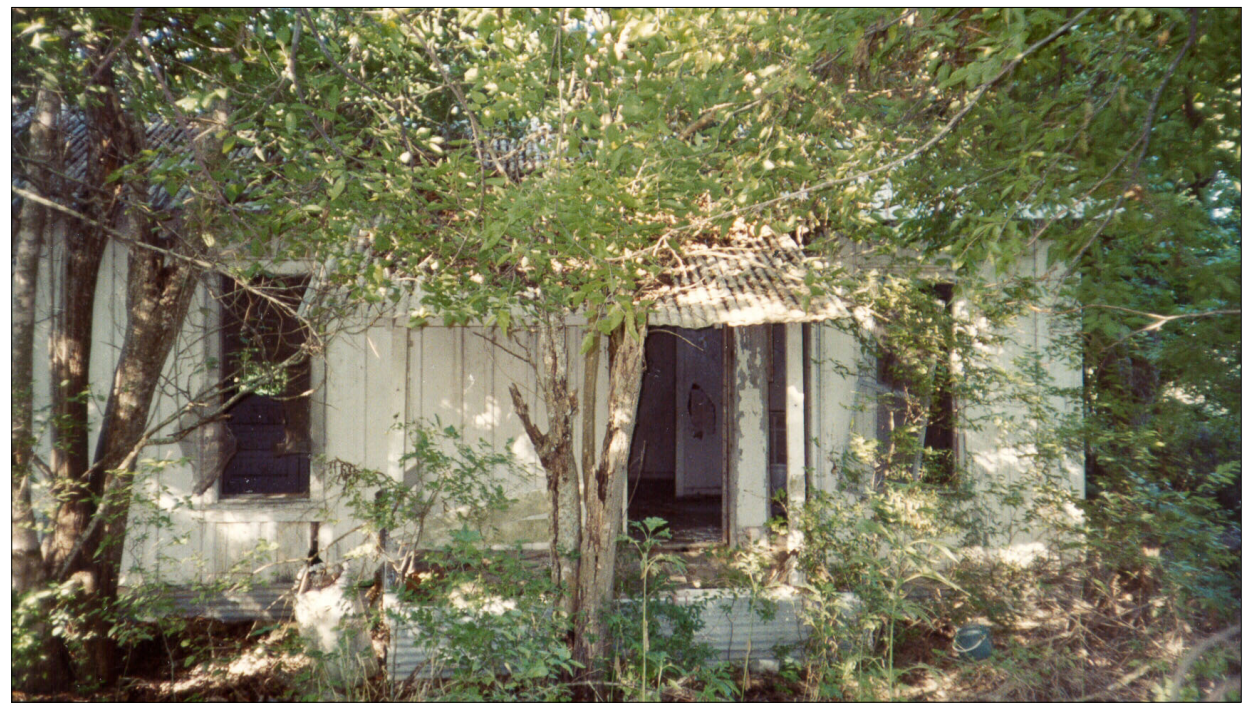

Figure 4-7. 1940s structure on site 41BX347.

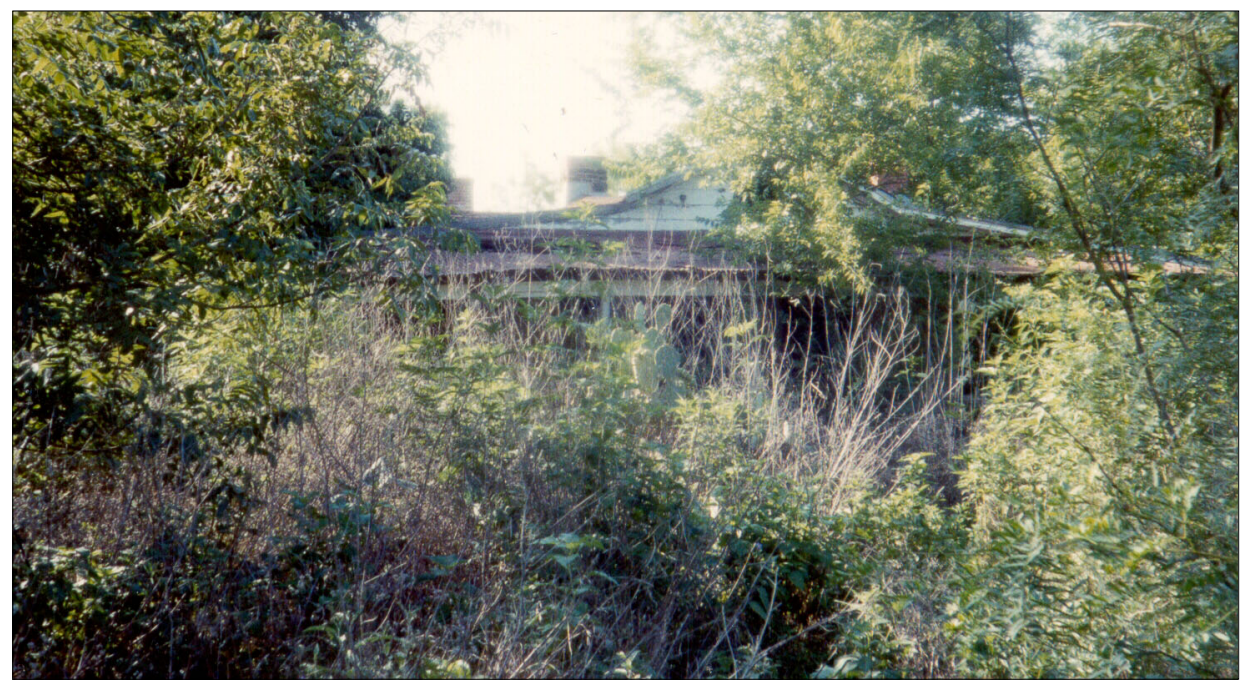

Figure 4-8. 1950s structure on site $41 B X 347$. 


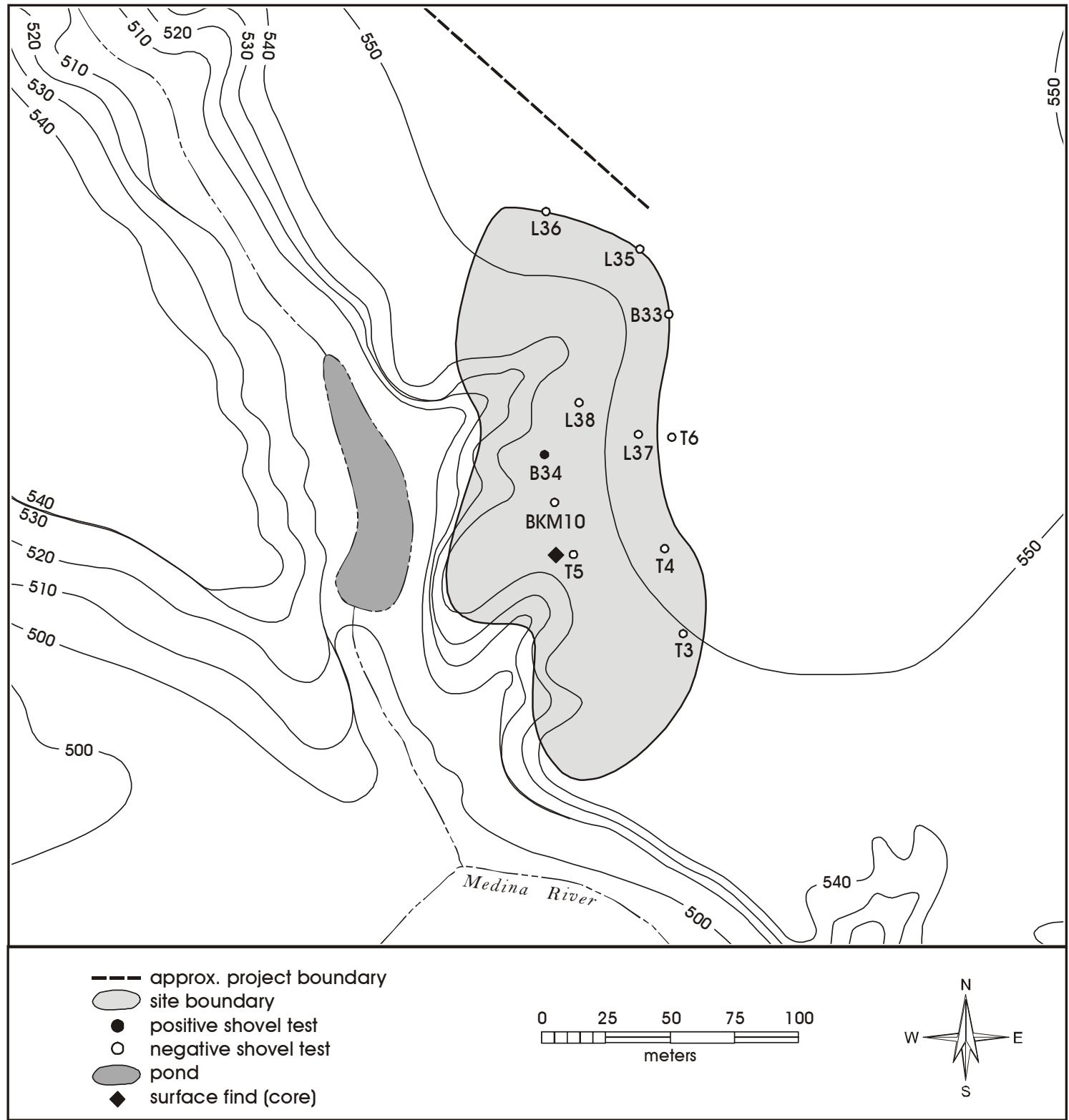

Figure 4-9. Site map of $41 B X 348$. 


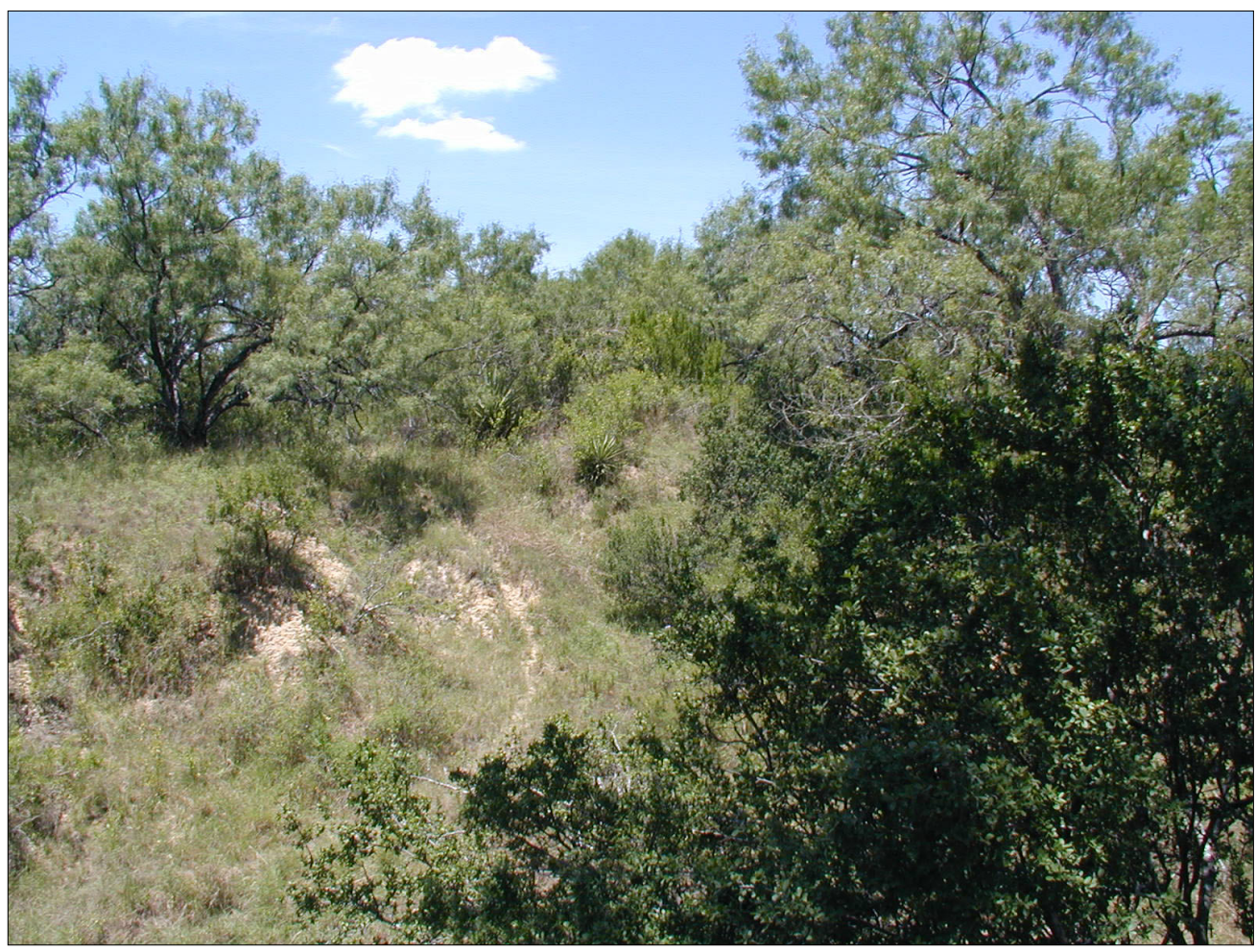

Figure 4-10. Photo of erosion at $41 B X 348$.

Table 4-2. Shovel Test Results from 41BX348

\begin{tabular}{|l|c|c|c|c|}
\hline Shovel Test No. & Max. Depth (cmbs) & Artifact & Count & Level of Artifact (cmbs) \\
\hline L35 & 60 & 0 & 0 & 0 \\
\hline L36 & 60 & 0 & 0 & 0 \\
\hline L37 & 60 & 0 & 0 & 0 \\
\hline B33 & 60 & 0 & 0 & 0 \\
\hline B34 & 60 & Debitage & 1 & $1(0-10)$ \\
\hline B34 & 60 & Debitage & 1 & $4(30-40)$ \\
\hline T3 & 60 & 0 & 0 & 0 \\
\hline T4 & 60 & 0 & 0 & 0 \\
\hline T5 & 60 & 0 & 0 & 0 \\
\hline T6 & 60 & 0 & 0 & 0 \\
\hline BKM10 & 60 & 0 & 0 & 0 \\
\hline
\end{tabular}




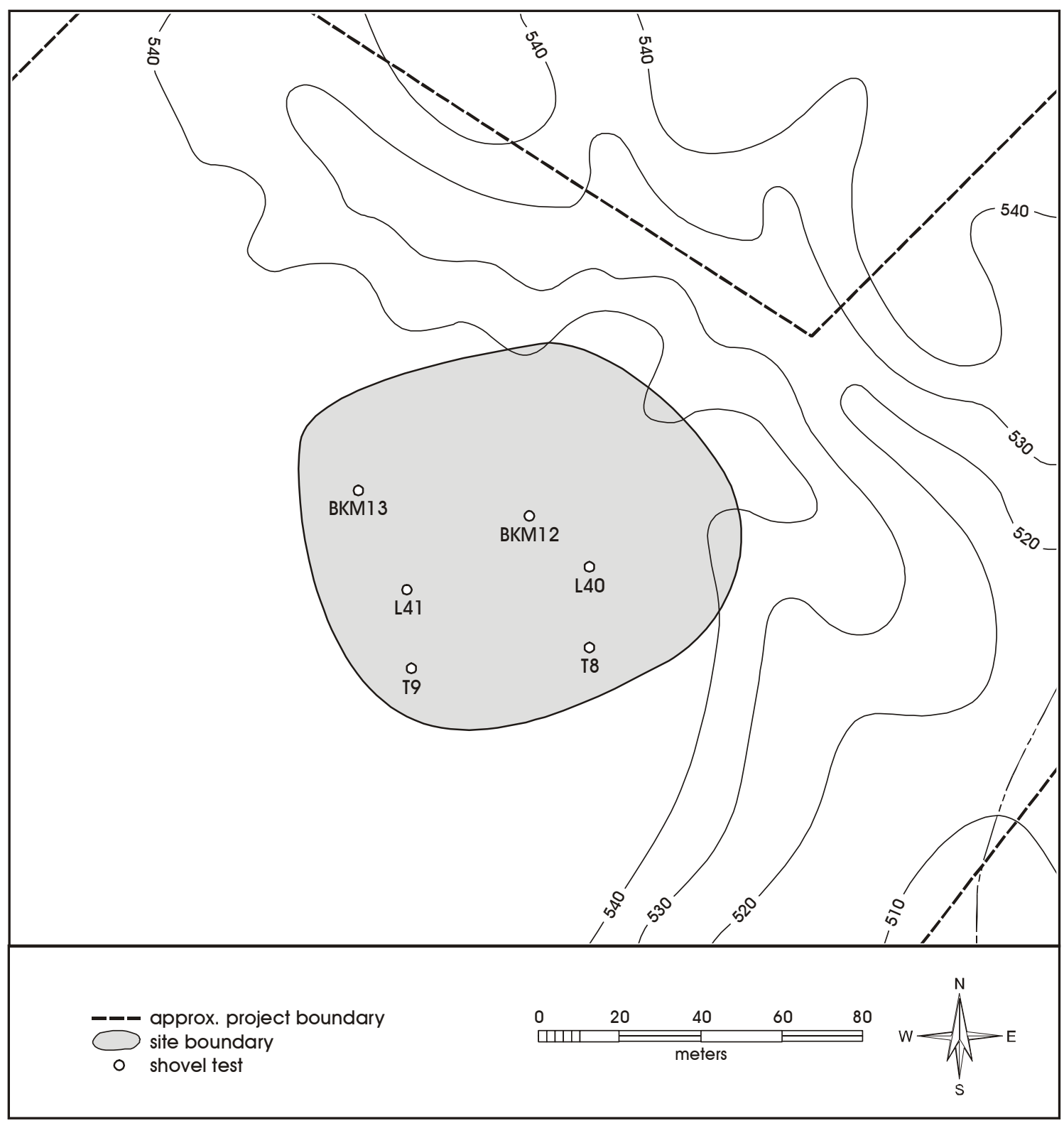

Figure 4-11. Site map of $41 B X 350$.

\section{$41 B \times 519$}

A proposed park trail will impact the center of this site and an existing road presently crosses the site (Figure 4-14). Although a wood-framed structure was noted on site during the original survey, no structures were present at the time of the CAR revisit. It appears that the structure may have been demolished leaving no trace of its former location. Erosional gullies in the vicinity of the site contained boards, tin, and other household hardware
(Figure 4-15). It is suspected that these debris piles may represent the remnants of the former structure. The surface survey also revealed a prehistoric component consisting of a lithic scatter about 90 meters south of the original site boundary. The lithic scatter consisted of unmodified debitage. Historic debris continued into the area linking the two components. The new findings resulted in the redefinition of the site as a multicomponent site and the extension of its boundary to encompass the additional surface scatter (Figure 4-14). 


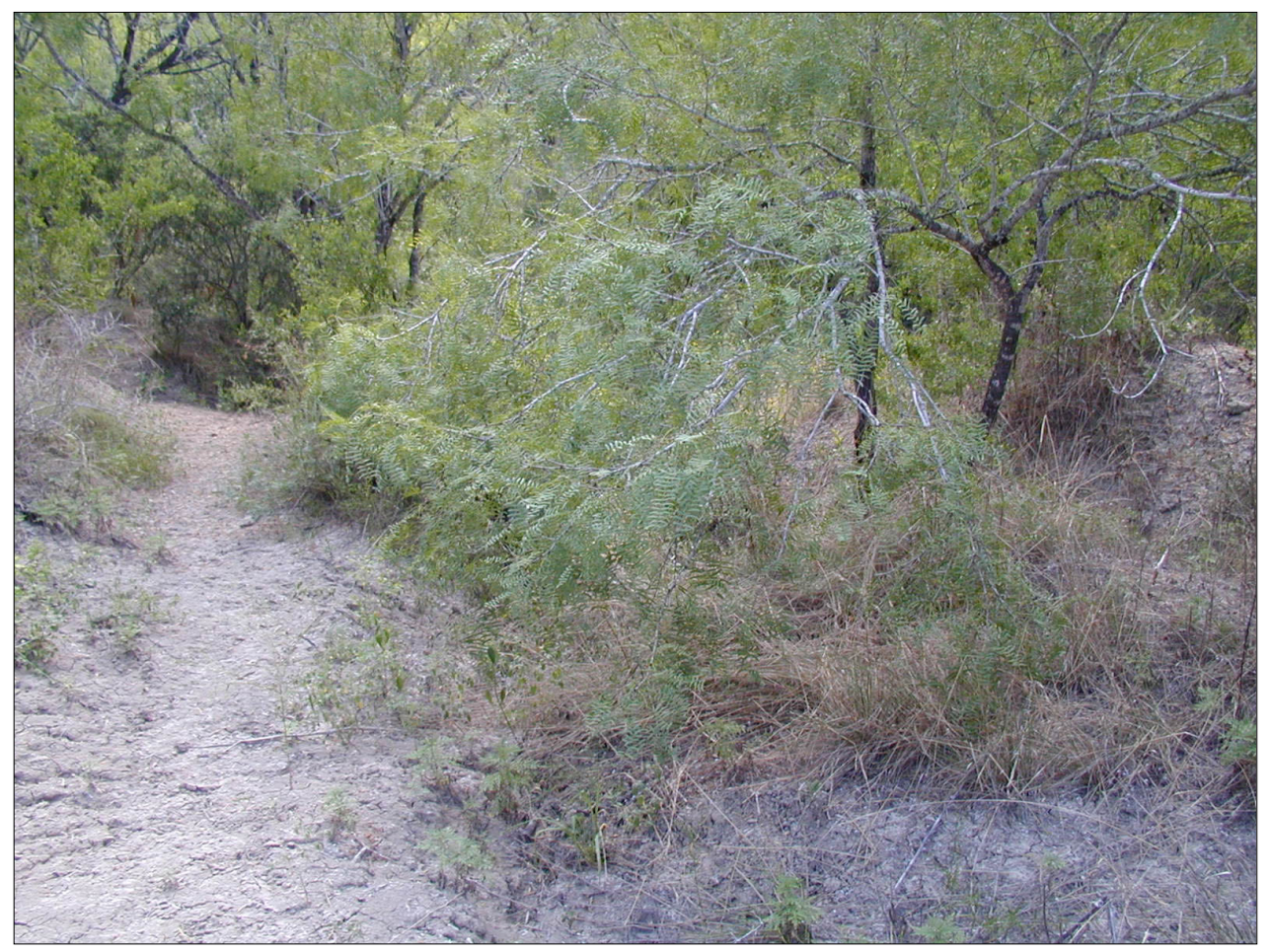

Figure 4-12. Photo of erosion at $41 B X 350$.

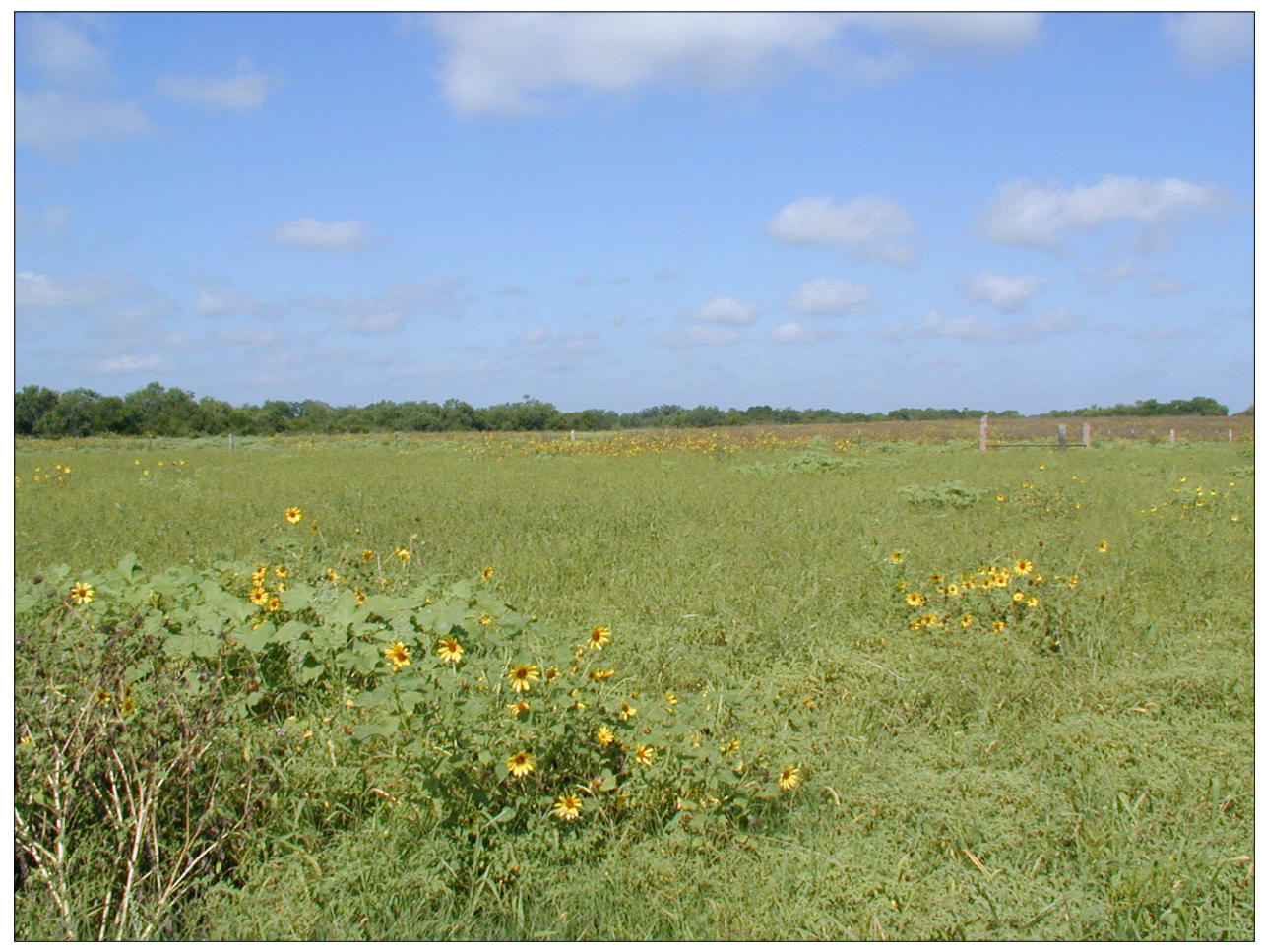

Figure 4-13. Photo of plowed field at $41 B X 350$. 


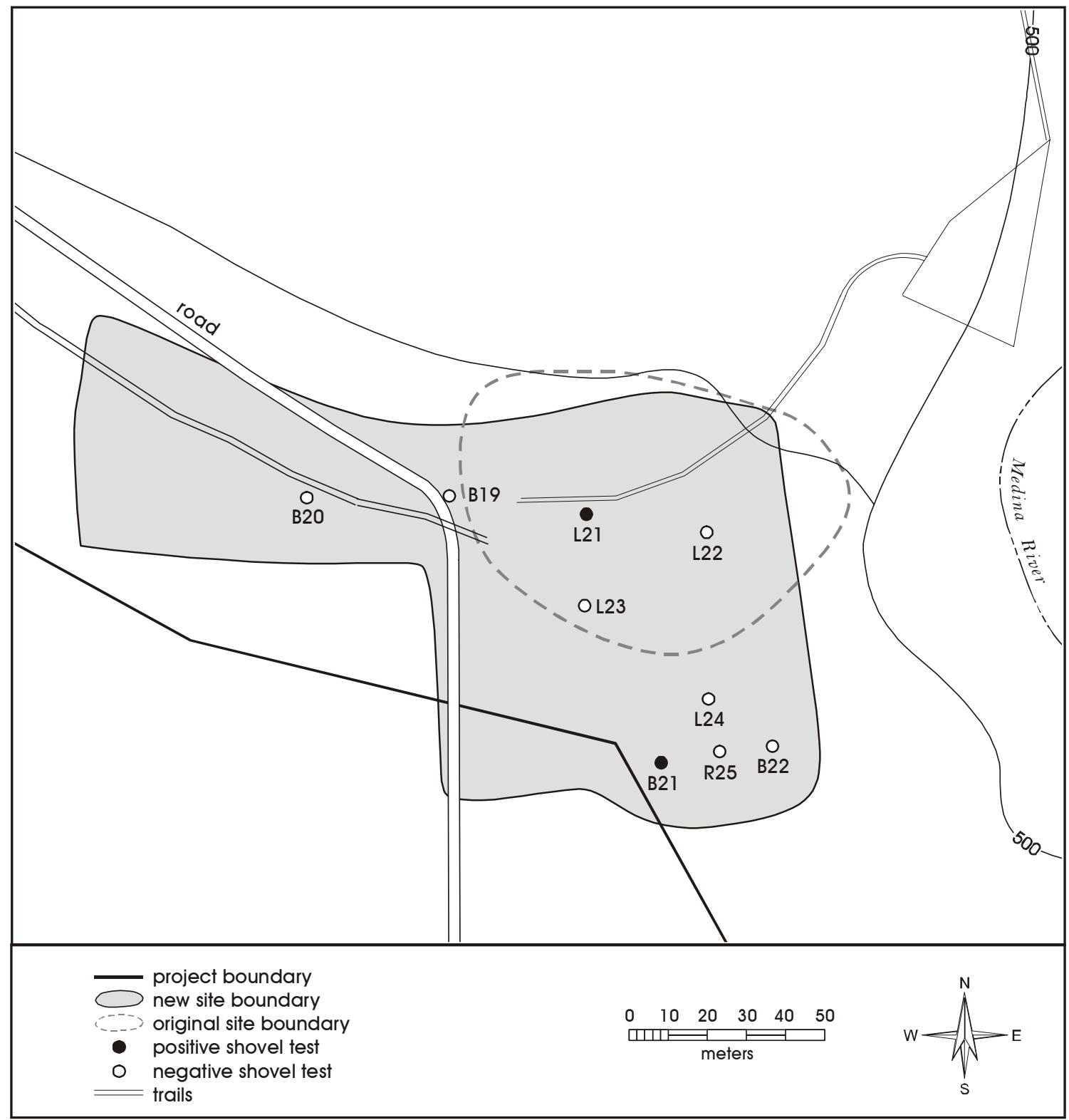

Figure 4-14. Site map of $41 B X 519$.

Nine shovel tests were excavated at the time of the revisit. They revealed silty clay to clay loam soils. Two shovel tests were positive, containing a historic ceramic (ST B21) and metal (ST L21) in the upper $10 \mathrm{~cm}$ (Table 4-3). Given the removal of the historic structure, the surface disturbance that accompanied this action and the sparse prehistoric material present on site, it is concluded that the site has very limited research potential.

\section{$41 \mathrm{~B} \times 675$}

No proposed park development will directly impact the site of the Thompson Cemetery (Figure 4-16). Although the cemetery was originally described as having at least one grave surrounded by an iron fence and a second grave as having a headstone and footstone, no evidence of the ornate wrought iron fence or headstones were encountered during the CAR revisit of the Thompson Cemetery. No shovel tests were excavated due to the uncertainty of grave locations. 


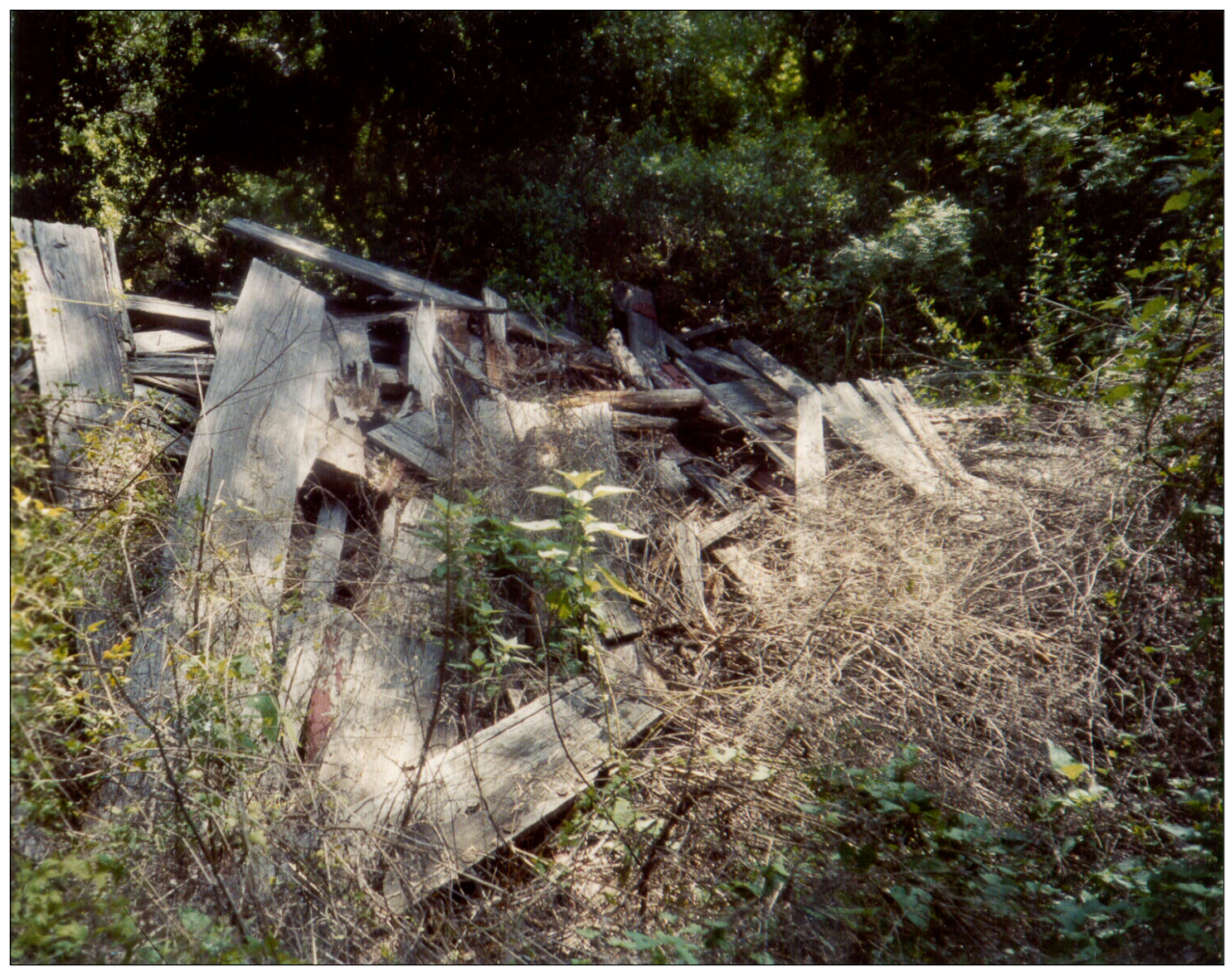

Figure 4-15. Photo of modern debris at 41BX519.

Table 4-3. Shovel Test Results from 41BX519

\begin{tabular}{|l|c|c|c|c|}
\hline Shovel Test No. & Max. Depth (cmbs) & Artifact & Count & Level of Artifact (cmbs) \\
\hline Surface & 0 & White earthernware & 1 & Surface \\
\hline R25 & 60 & 0 & 0 & 0 \\
\hline L21 & 35 & Caster & 1 & $1(0-10)$ \\
\hline L22 & 60 & 0 & 0 & 0 \\
\hline L23 & 60 & 0 & 0 & 0 \\
\hline L24 & 60 & 0 & 0 & 0 \\
\hline B19 & 60 & 0 & 0 & 0 \\
\hline B20 & 60 & 0 & 0 & 0 \\
\hline B21 & 60 & Stoneware & 1 & $1(0-10)$ \\
\hline B22 & 60 & 0 & 0 & 0 \\
\hline
\end{tabular}

\section{$41 \mathrm{BX} 837$}

This site is intersected by the park boundary but no proposed trails will impact this area (Figure 4-17). The site was initially reported as having both prehistoric and historic components (THC 2003). The historic component may have dated to the early- to midnineteenth century. The prehistoric component was evident on surface but no signs of the post-1950 structures were noted on the portion of the site within the park boundary. The open, plowed field to the south of the park boundary was surface inspected with no indication of cultural material, despite nearly 100 percent surface visibility. The northern portion of the site is 


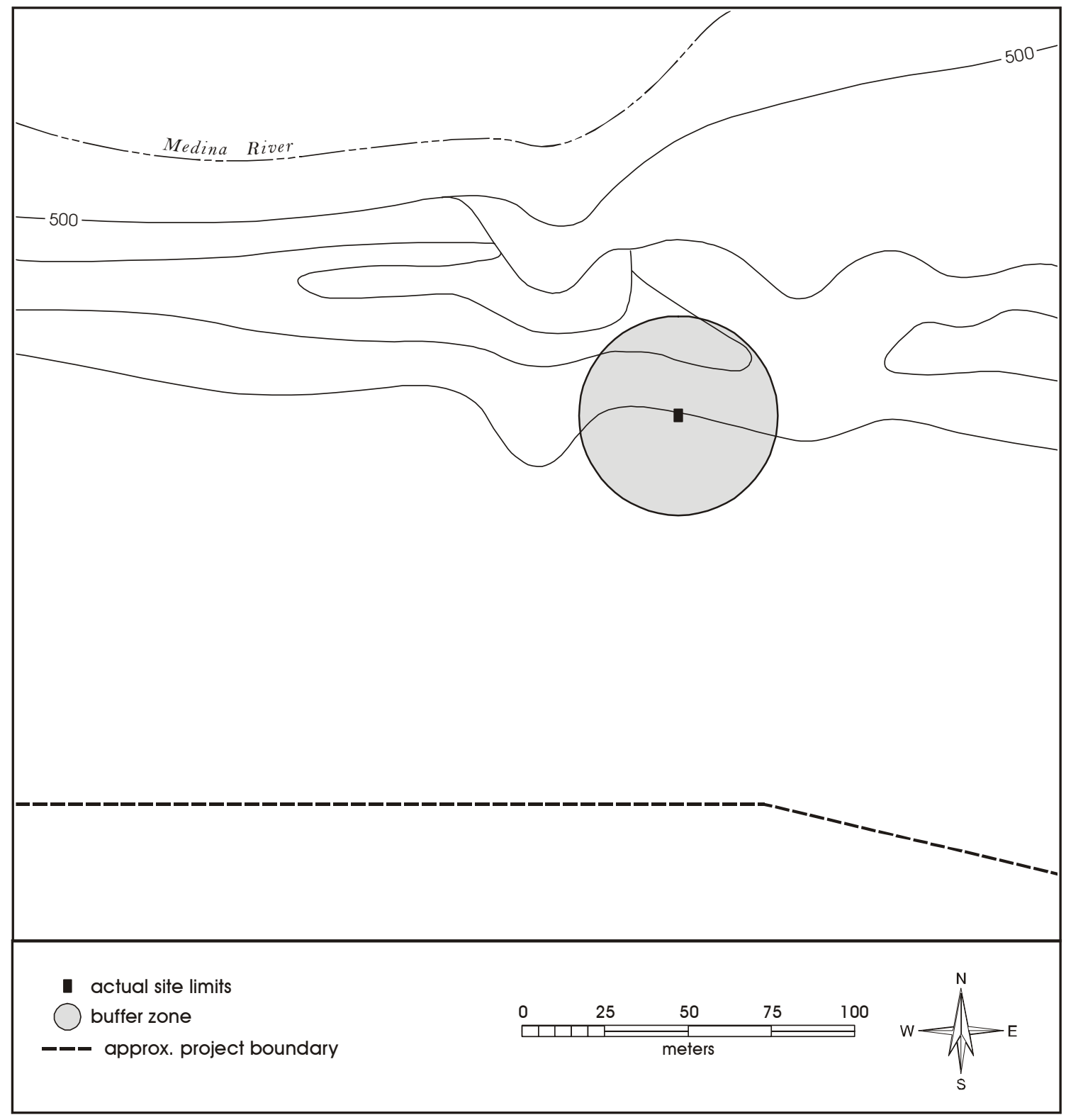

Figure 4-16. Site map of $41 B X 675$. 


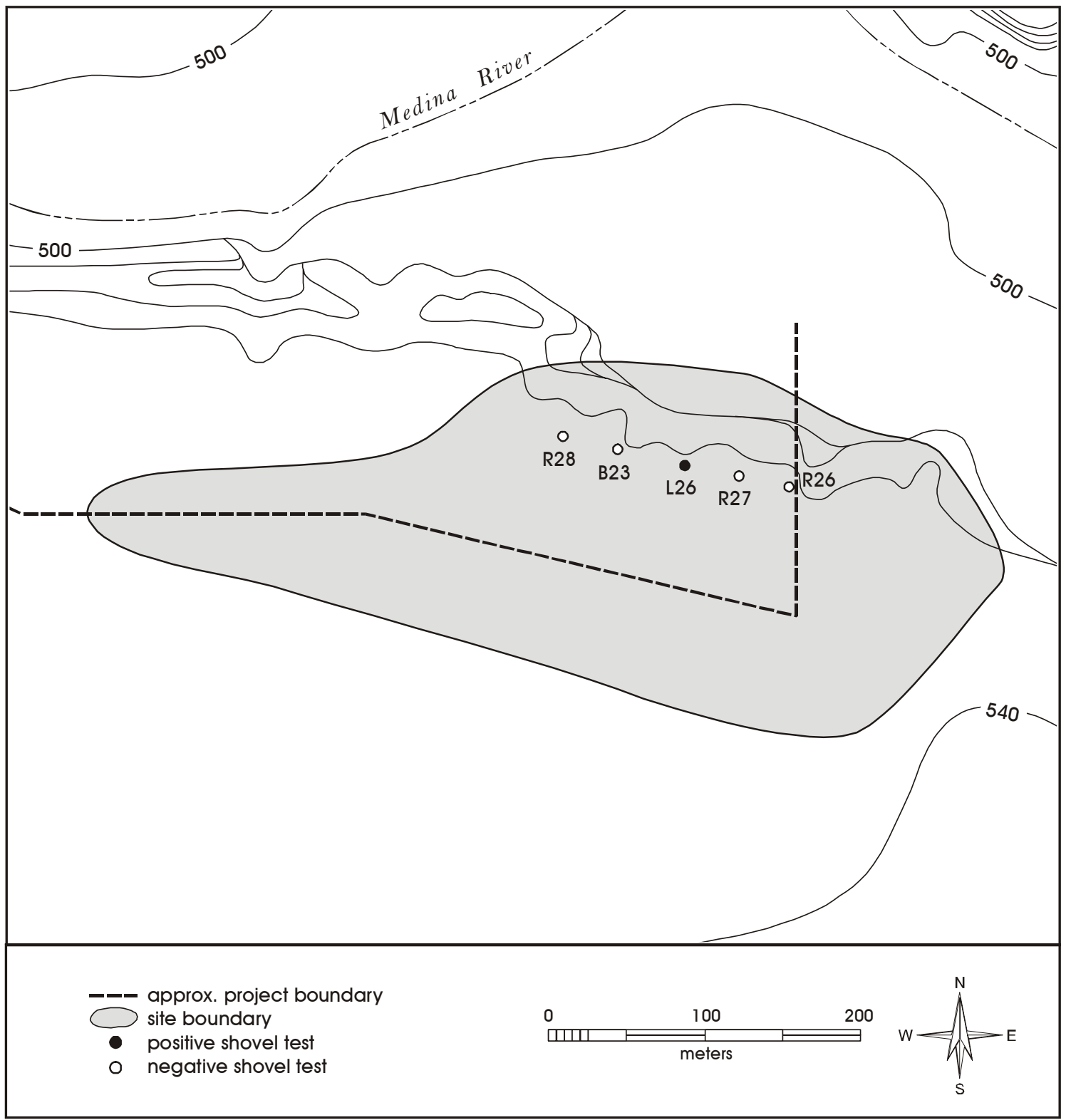

Figure 4-17. Site map of $41 B X 837$. 
heavily eroded, therefore, only five shovel tests were excavated within the portion of the site found inside the proposed park boundary. No shovel test recovered prehistoric materials, but one historic unidentified metal artifact was recovered in ST L26, Level 4 (30-40 cmbs; Table 4-4). Shovel tests revealed that soils in this site area consist of brown silty clay.

\section{$41 B \times 857$}

Proposed park trails are planned for this portion of the project area and an existing two-track dirt road dissects the site area at the present time (Figure 4-18). Despite several attempts to identify historic or prehistoric artifacts on surface, the extensive walkover of the site failed to find any such artifacts. It is likely that severe erosion has displaced any surface cultural materials associated with the Palo Alto Crossing. In addition, no artifacts were recovered from the five shovel tests excavated on site. Historic concrete bridge pilings are apparently all that remain of this Colonial-era site (Figure 4-19).

\section{Newly Recorded Sites}

During survey of the proposed Medina River Park, four new archaeological sites were encountered.

\section{$41 \mathrm{BX} 1577$}

A proposed parking facility is planned just north of the 41BX1577 site area (Figure 4-20). This site is on an upper terrace of the Medina River at 540 feet AMSL. SH 16 is approximately 220-240 meters northwest of the site. The site covers an area that is approximately 80 meters by 35 meters. Exposed on the plowed surface that makes up the site area was a dense scatter of flakes and burned rock. The flakes represent the remains of stone tool manufacture and the burned rock fragments are the remnants of rock-lined hearths. Fieldwork carried out on the site consisted of two phases. The first phase consisted of the excavation of 17 shovel tests on this site. Although the site has been plowed, the subsurface disturbance appears to be limited to the upper $30 \mathrm{~cm}$. An intact burned rock feature was identified at $60 \mathrm{cmbs}$ in ST B2. Soils encountered in the shovel tests consist of grayish brown sandy silty clay. Twelve of the 17 shovel tests were positive, yielding an abundance of burned rock, flakes, and a single Goliad ceramic (Table 4-5). A small thin biface, a possible arrow point preform, made from a blade was recovered from ST R4 in Level $1(0-10 \mathrm{cmbs})$. The Goliad ceramic and the associated lithic material are evidence of a Late Prehistoric, probably Toyah Phase, component at the site.

Following the fieldwork and site revisits, CAR personnel (Steve Tomka and Antonia Figueroa), Kevin Conner of Carter \& Burgess, Lisa Morris of the SAPRD, and Mark Denton of the THC met regarding the results of the survey. At this meeting it was requested that the northern boundary of 41BX1577 be marked off and this data be provided to the Client and the SAPRD to ensure that construction will not impact portions of the site that appear to contain research potential. Fieldwork to accomplish this task was carried out on August 21, 2003. Six additional shovel tests (STs BKM 20-22 and STs T17-T19) were excavated in an area that was previously defined as the northern portion of the site but had not been shovel tested to identify whether buried cultural deposits were present. The additional shovel tests recovered no cultural materials. As part of this same visit, CAR personnel used a GPS unit to map in two control points to identify the site's northern boundary. In turn, this information was provided to the Client to avoid impact to the site during the proposed park development.

Table 4-4. Shovel Test Results from 41BX837

\begin{tabular}{|l|c|c|c|c|}
\hline Shovel Test No. & Max. Depth (cmbs) & Artifact & Count & Level of Artifact (cmbs) \\
\hline R26 & 60 & 0 & 0 & 0 \\
\hline R27 & 60 & 0 & 0 & 0 \\
\hline R28 & 60 & 0 & 0 & 0 \\
\hline L26 & 60 & Metal & 1 & $4(30-40)$ \\
\hline B23 & 60 & 0 & 0 & 0 \\
\hline
\end{tabular}




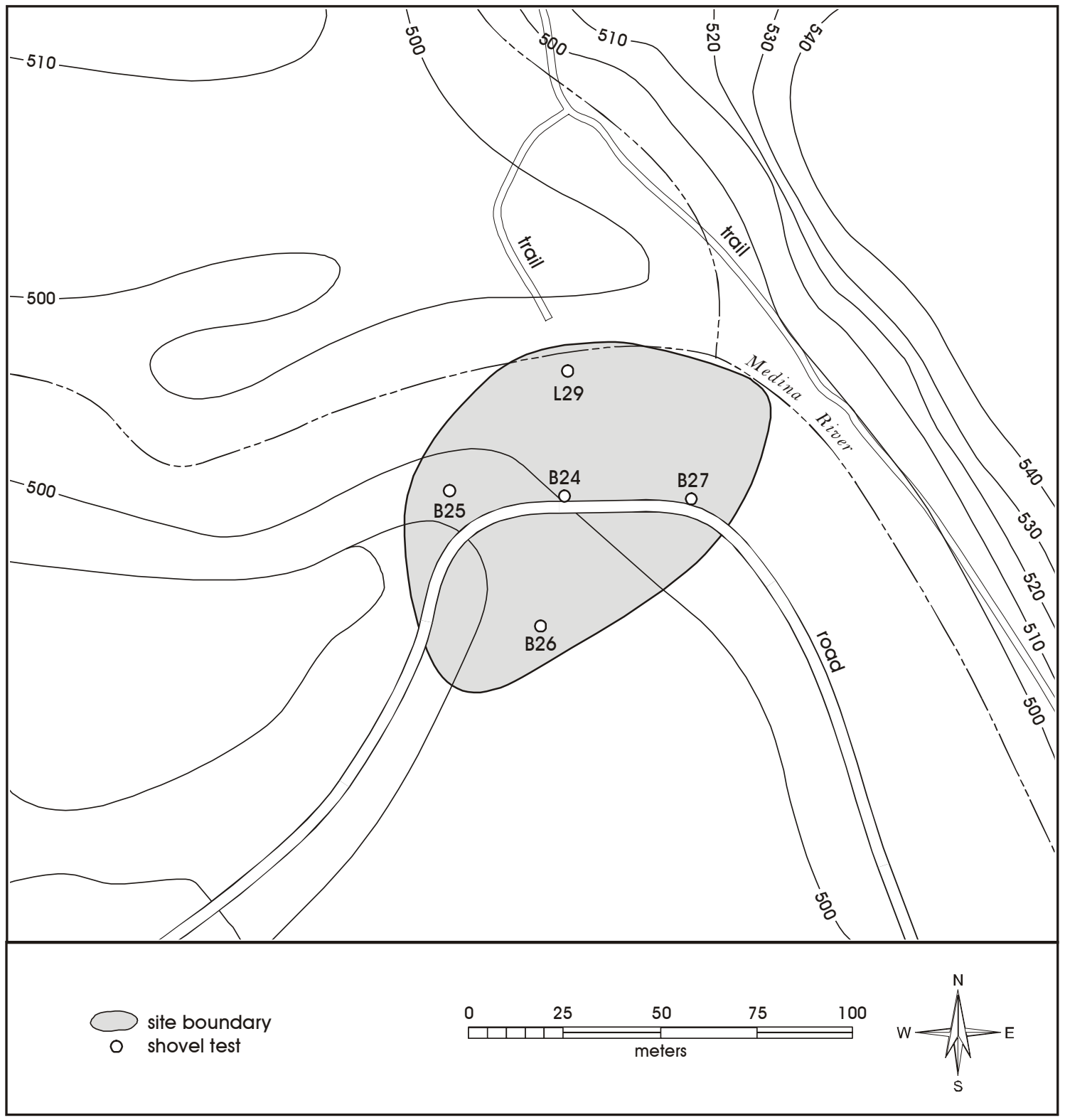

Figure 4-18. Site map of $41 B X 857$. 


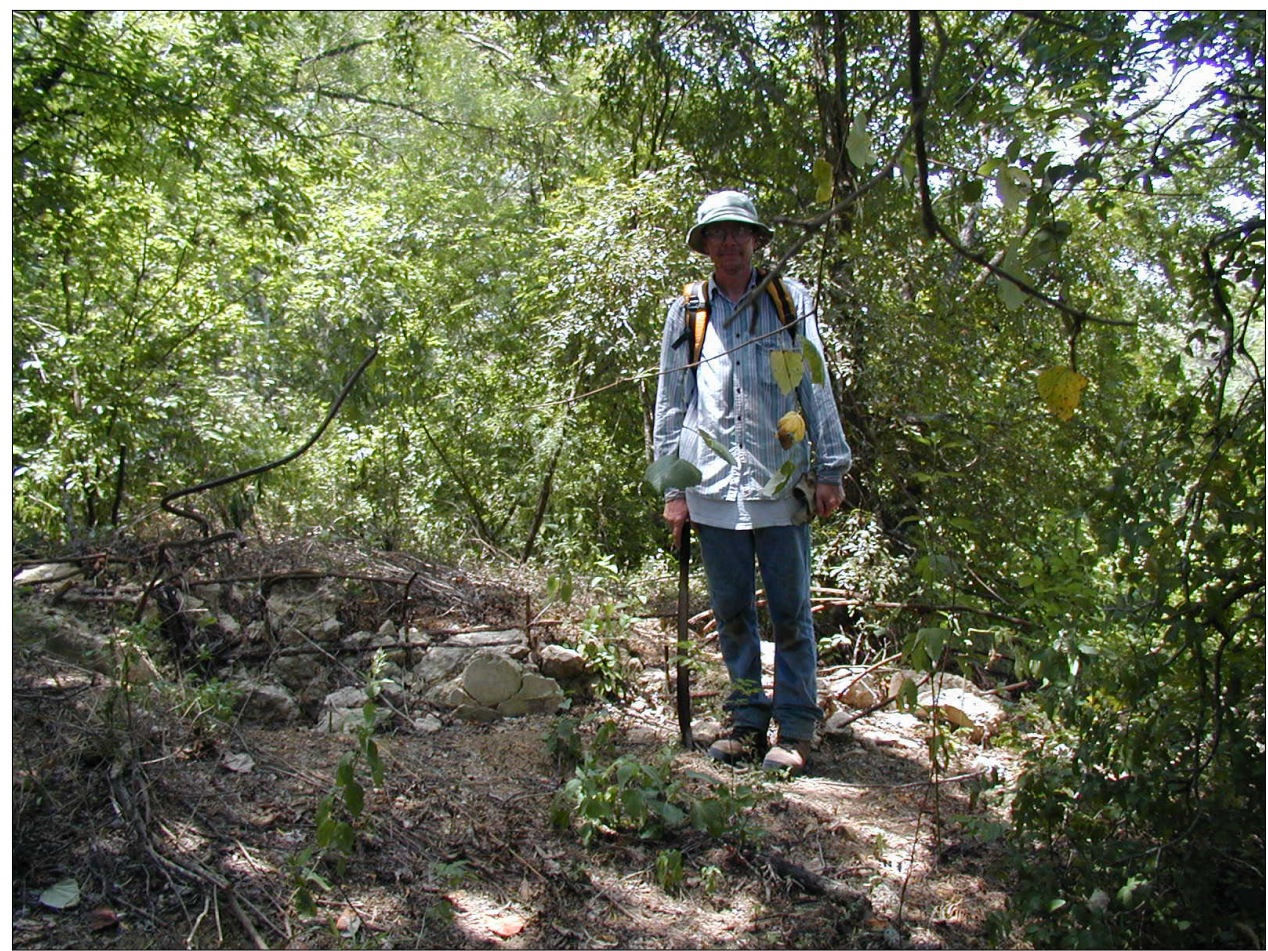

Figure 4-19. Photo of bridge pilings at $41 B X 857$.

\section{$41 \mathrm{BX} 1578$}

There are no proposed park developments that will directly impact site 41BX1578 (Figure 4-21). This multicomponent site is located in the southeastern portion of the project area, just north of the Medina River (approximately $100-120 \mathrm{~m}$ ). Applewhite Road is about $1.4 \mathrm{~km}$ to the east of the site. The site is on the northern edge of the river terrace at 540 AMSL. The majority of the site consists of an open, plowed field that is eroding into a drainage in the vicinity of the southern boundary of the site. Site $41 B X 1578$ is roughly 90 meters by 30 meters in size. Eight shovel tests were excavated on this site.

Shovel tests showed that soils at the site consist primarily of tan silty clay with depositional gravels in the upper levels. Plow damage is evident on some of the larger rocks that appear to be mechanically fractured and are rust stained. The depth of plow damage is estimated to be approximately $30 \mathrm{cmbs}$. Two of the eight shovel tests were positive (ST R31 and ST B28). The buried materials consisted of brown glass and burned rock in Level 1
$(0-10 \mathrm{cmbs})$ of ST R31 and one piece of debitage in Level 2 (10-20 cmbs) of ST B28 (Table 4-6). Although the subsurface materials are sparse and appear to be contained entirely within the plow zone, abundant cultural material is present on the surface. Observed prehistoric artifacts on the surface included FCR, chipped stone (large primary flakes, $\mathrm{n}=20+$; expedient tools, $\mathrm{n}=9$; cores, $n=4)$, hammer stones $(n=2)$, mussel shell, and Goliad pottery $(n=3)$. Historic ceramics, including ironstone and white earthenwares, were also observed. Due to the erosion and lack of intact buried materials, the site retains minimal research potential.

\section{$41 \mathrm{BX} 1579$}

No proposed trail developments are planned to directly impact site 41BX1579 (Figure 4-22). This prehistoric site is located in the north-central portion of the project area, and straddles a large utility corridor. SH 16 is located approximately $1 \mathrm{~km}$ west of the site. The site is on an upland margin just north of the floodplain (530 540 feet AMSL), and approximately 250 meters north of 


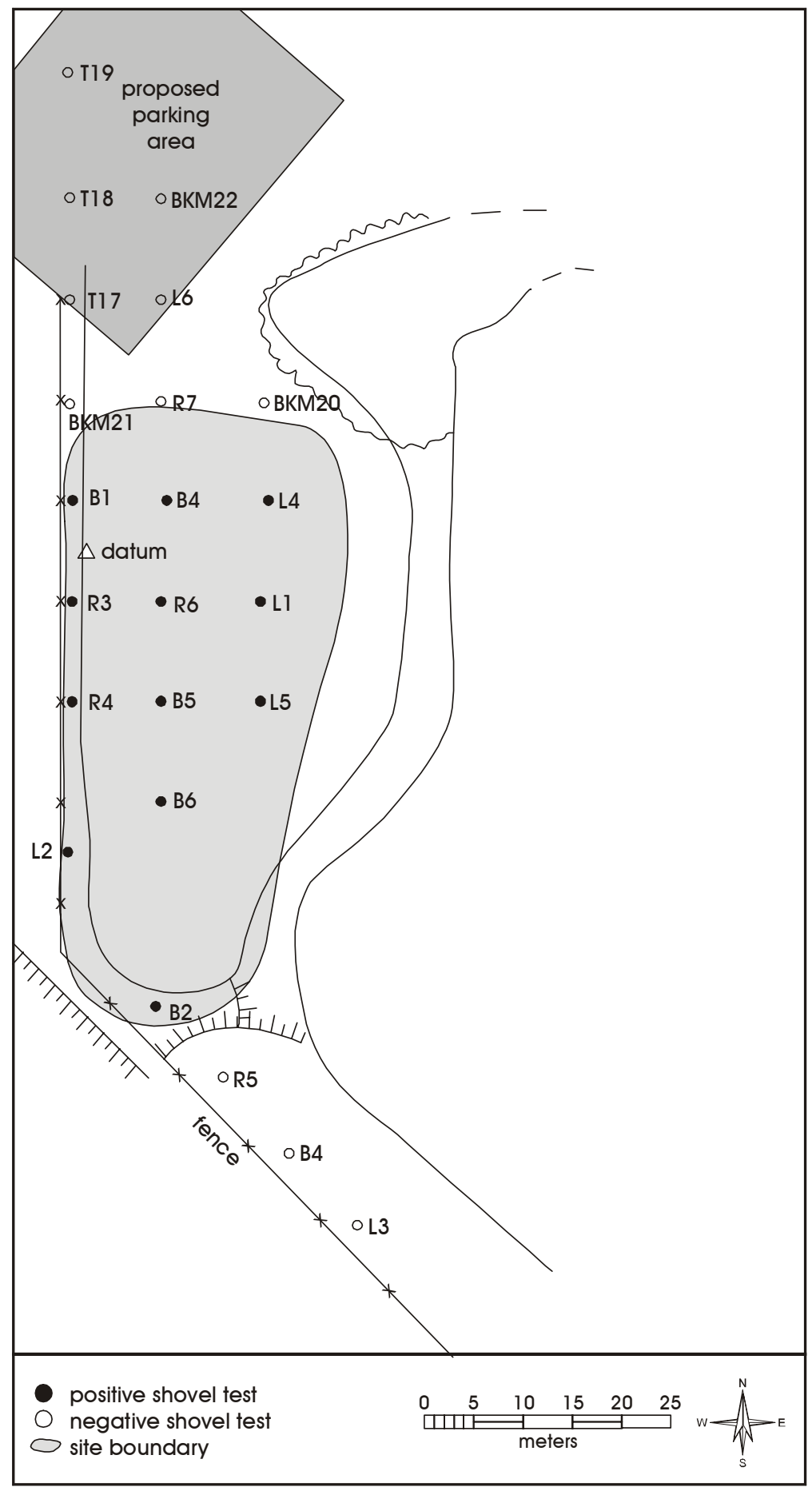

Figure 4-20. Site map of $41 B X 1577$. 
Table 4-5. Shovel Test Results from 41BX1577

\begin{tabular}{|c|c|c|c|c|}
\hline Shovel Test No. & Max. Depth (cmbs) & Artifact & Count & Level of Artifact (cmbs) \\
\hline R3 & 60 & Debitage & 3 & $1(0-10)$ \\
\hline R3 & 60 & Burned Rock & 1 & $1(0-10)$ \\
\hline R3 & 60 & Utilized Flake & 1 & $1(0-10)$ \\
\hline R4 & 60 & Debitage & 2 & $1(0-10)$ \\
\hline R4 & 60 & Burned Rock & 2 & $1(0-10)$ \\
\hline $\mathrm{R} 4$ & 60 & Biface & $\overline{1}$ & $1(0-10)$ \\
\hline R5 & 60 & 0 & 0 & 0 \\
\hline R6 & 60 & Utilized Flake & 1 & $1(0-10)$ \\
\hline R6 & 60 & Debitage & 3 & $4(30-40)$ \\
\hline R6 & 60 & Burned Rock & 1 & $4(30-40)$ \\
\hline R6 & 60 & Charcoal & 1 & $4(30-40)$ \\
\hline R7 & 60 & 0 & 0 & 0 \\
\hline L1 & 60 & Debitage & 1 & $1(0-10)$ \\
\hline L2 & 60 & Debitage & 1 & $4(30-40)$ \\
\hline L3 & 60 & 0 & 0 & 0 \\
\hline L4 & 60 & Debitage & 2 & $4(30-40)$ \\
\hline$\overline{\mathrm{L} 4}$ & 60 & Biface & 2 & $4(35)$ \\
\hline $\mathrm{L} 5$ & 60 & Burned Rock & 1 & $1(0-10)$ \\
\hline L5 & 60 & Burned Rock & 1 & $6(50-60)$ \\
\hline L6 & 60 & 0 & 0 & 0 \\
\hline $\mathrm{B} 1$ & 60 & Goliad Ceramic & 1 & $1(0-10)$ \\
\hline B1 & 60 & Debitage & 3 & $1(0-10)$ \\
\hline$\overline{B 1}$ & 60 & Debitage & 1 & $2(10-20)$ \\
\hline$\overline{\mathrm{B} 1}$ & 60 & Core & 1 & $1(0-10)$ \\
\hline B2 & 40 & Ochre & 1 & $2(10-20)$ \\
\hline B3 & 60 & 0 & 0 & 0 \\
\hline B4 & 60 & Burned Clay & 1 & $2(10-20)$ \\
\hline B5 & 60 & Burned Clay & 2 & $2(10-20)$ \\
\hline B5 & 60 & Debitage & 2 & $3(20-30)$ \\
\hline$\overline{B 5}$ & 60 & Burned Rock & 2 & $5(40-50)$ \\
\hline B5 & 60 & Debitage & 2 & $2(10-20)$ \\
\hline B6 & 60 & Debitage & 1 & $4(30-40)$ \\
\hline B6 & 60 & Debitage & 1 & $5(40-50)$ \\
\hline B6 & 60 & Burned Rock & 2 & $6(50-60)$ \\
\hline BKM22 & 60 & 0 & 0 & 0 \\
\hline BKM21 & 60 & 0 & 0 & 0 \\
\hline BKM20 & 60 & 0 & 0 & 0 \\
\hline T19 & 60 & 0 & 0 & 0 \\
\hline T18 & 60 & 0 & 0 & 0 \\
\hline T17 & 60 & 0 & 0 & 0 \\
\hline
\end{tabular}


the Medina River. Approximately 20-30 $\mathrm{cm}$ of the site's upper deposits have been heavily disturbed by pig wallows. The site measures approximately 110 meters by 50 meters. A moderate number of artifacts are scattered across the surface, including flakes and burned rock, and are present within the exposed areas of pig wallows. Fourteen shovel tests were excavated on site, nine were positive. The depth of cultural deposits range from $0-60 \mathrm{cmbs}$ (Table 4-7). The majority of artifacts were encountered in Level 3 (20-30 cmbs) and below, in brown clay to sandy loam. Though no diagnostic materials were recovered, the presence of surface and intact subsurface materials suggests moderate research potential for the site.

\section{$41 B X 1580$}

This site is in the southeastern portion of the project area where no direct and immediate park developments are planned (Figure 4-23). This prehistoric site is at 530-540 feet AMSL, with the Medina River approximately 350 meters to the south and Applewhite Road $1.5 \mathrm{~km}$ to the east. The size of the site is approximately 75 meters by 50 meters. The southern and

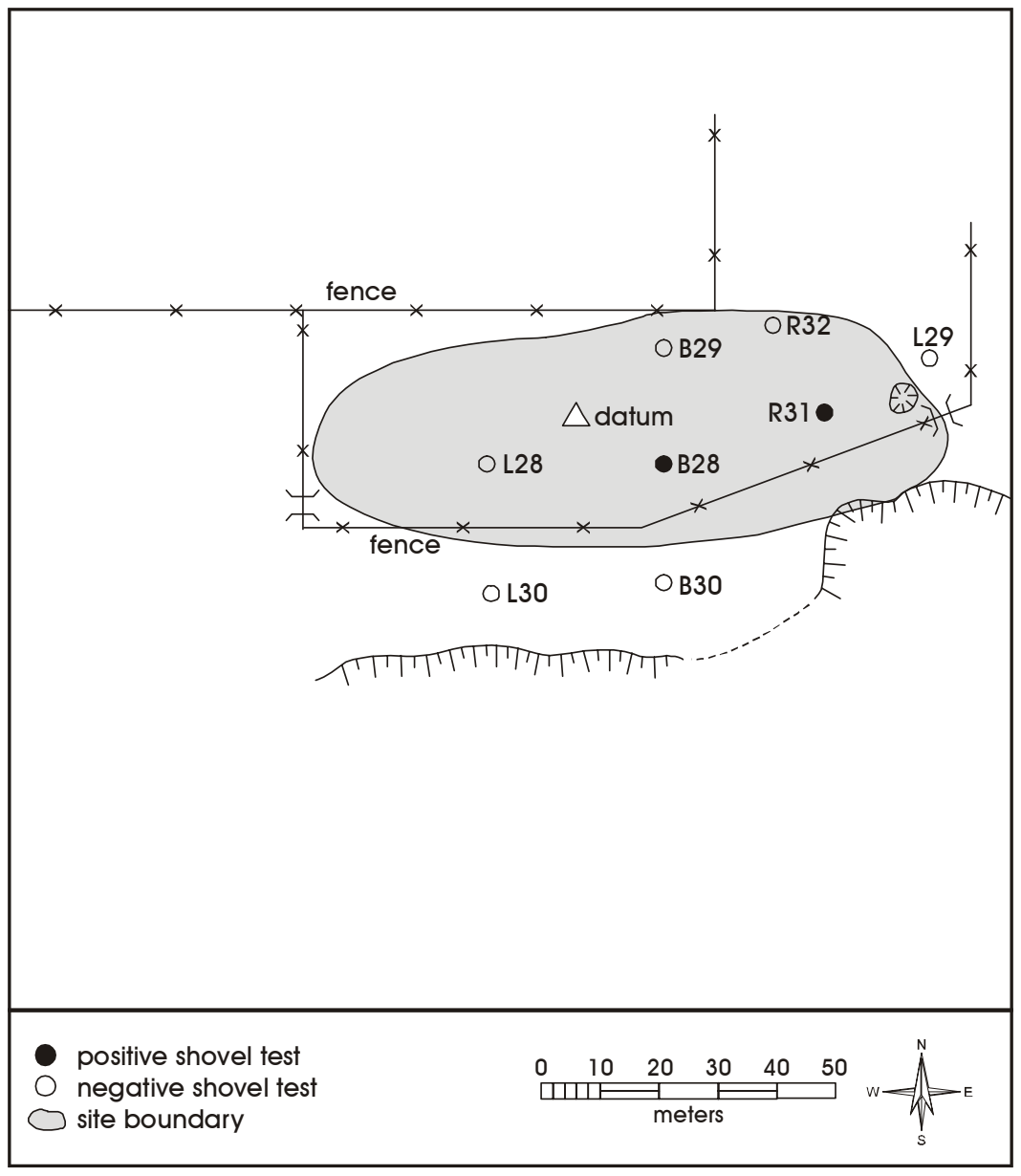

Figure 4-21. Site map of $41 B X 1578$.

Table 4-6. Shovel Test Results from 41BX1578

\begin{tabular}{|l|c|c|c|c|}
\hline Shovel Test No. & Max. Depth (cmbs) & Artifact & Count & Level of Artifact (cmbs) \\
\hline L32 & 60 & 0 & 0 & 0 \\
\hline L31 & 60 & 0 & 0 & 0 \\
\hline L30 & 60 & 0 & 0 & 0 \\
\hline R31 & 60 & Brown Glass & 1 & $1(0-10)$ \\
\hline R31 & 60 & Burned Rock & 1 & $1(0-10)$ \\
\hline R32 & 60 & 0 & 0 & 0 \\
\hline B28 & 60 & Debitage & 1 & $2(10-20)$ \\
\hline B29 & 60 & 0 & 0 & 0 \\
\hline B30 & 60 & & 0 & 0 \\
\hline Surface & 0 & White earthernware (transfer) & 1 & Surface \\
\hline Surface & 0 & Goliad ware & 3 & Surface \\
\hline Surface & 0 & Ironstone (maker mark) & 1 & Surface \\
\hline Surface & 0 & White earthernware (modern) & 4 & Surface \\
\hline
\end{tabular}




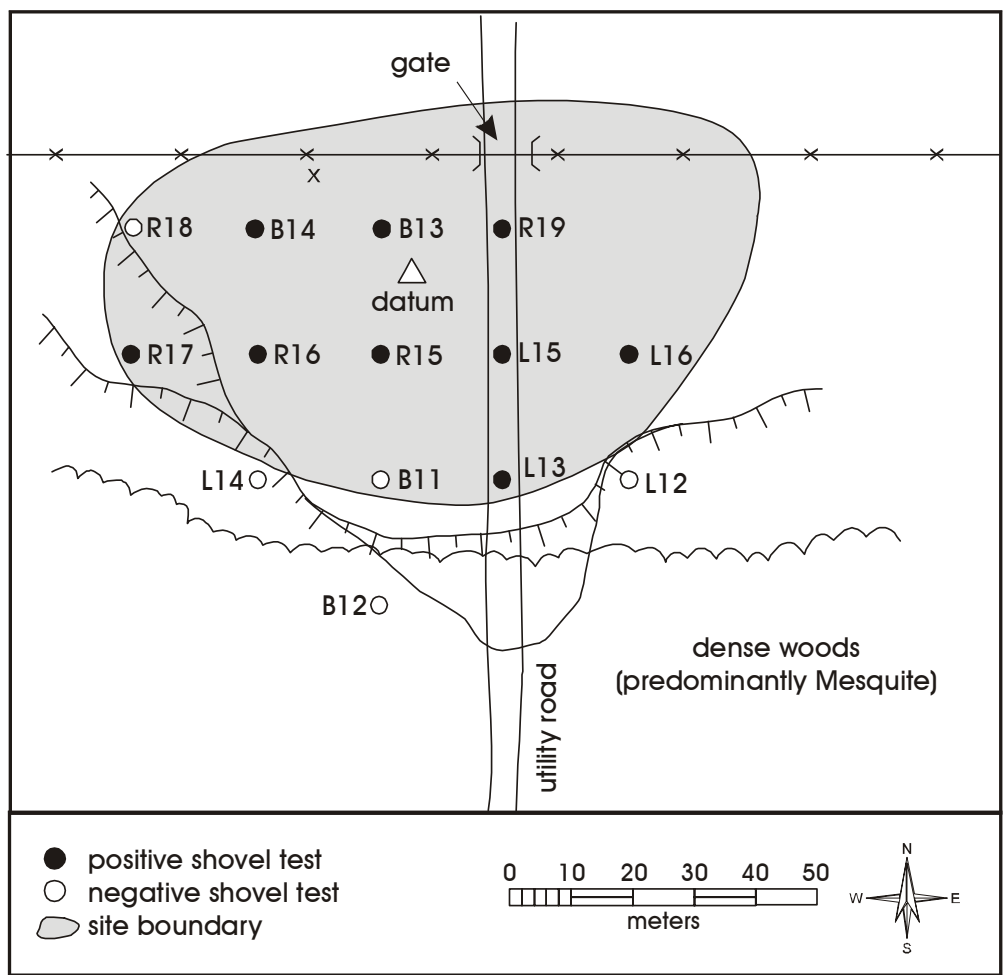

Figure 4-22. Site map of $41 B X 1579$.

eastern portions of the site are severely eroding into several cross-cutting drainages (Figure 4-24). The northern and western portions are comprised of an open, plowed field. The surface contains moderate densities of mussel shell, lithic debitage (flakes), and burned rock. A finely made biface fragment (dart point tip) was observed on surface (not collected) on the southern side of the site. It appears that the artifact distributions observed on surface are the result of slopewash that is slowly eroding materials into the adjacent gullies. Seven shovel tests were excavated on site. Soils in the shovel tests consisted of blocky clay loam. None of the shovel tests recovered buried cultural materials. Given the heavy erosion and lack of subsurface deposits, this site possesses low research potential. 
Table 4-7. Shovel Test Results from 41BX1579

\begin{tabular}{|l|c|l|c|c|}
\hline Shovel Test No. & Max. Depth (cmbs) & Artifact & Count & Level of Artifact (cmbs) \\
\hline L12 & 60 & 0 & 0 & 0 \\
\hline L13 & 60 & Debitage & 1 & $6(50-60)$ \\
\hline L14 & 60 & 0 & 0 & 0 \\
\hline L15 & 55 & Debitage & 1 & $1(0-10)$ \\
\hline L15 & 55 & Debitage & 1 & $2(10-20)$ \\
\hline L15 & 55 & Debitage & 3 & $3(20-30)$ \\
\hline L15 & 55 & Mussel Shell & 1 & $3(20-30)$ \\
\hline L16 & 60 & Debitage & 1 & $1(0-10)$ \\
\hline L16 & 60 & Burned Rock & 1 & $5(40-50)$ \\
\hline L16 & 60 & Debitage & 3 & $6(50-60)$ \\
\hline L16 & 60 & Mussel Shell & 1 & $6(50-60)$ \\
\hline B11 & 60 & 0 & 0 & 0 \\
\hline B12 & 60 & 0 & 0 & 0 \\
\hline B13 & 60 & Debitage & 2 & $4(30-40)$ \\
\hline B13 & 60 & Debitage & 1 & $5(40-50)$ \\
\hline B13 & 60 & Debitage & 7 & $6(50-60)$ \\
\hline B14 & 60 & Debitage & 1 & $3(20-30)$ \\
\hline R15 & 60 & Debitage & 2 & $3(20-30)$ \\
\hline R15 & 60 & Burned Rock & 1 & $3(20-30)$ \\
\hline R15 & 60 & Debitage & 2 & $4(30-40)$ \\
\hline R16 & 60 & Debitage & 2 & $3(20-30)$ \\
\hline R17 & 60 & Debitage & 1 & $3(20-30)$ \\
\hline R18 & 60 & 0 & 0 & 0 \\
\hline R19 & 60 & Debitage & 1 & $2(10-20)$ \\
\hline R19 & 60 & Debitage & 3 & $3(20-30)$ \\
\hline R19 & 60 & Debitage & 5 & $4(30-40)$ \\
\hline R19 & 60 & Burned Rock & 2 & $4(30-40)$ \\
\hline R19 & 60 & Burned Rock & 5 & $5(40-50)$ \\
\hline R19 & 60 & Debitage & 2 & $6(50-60)$ \\
\hline R19 & & & & $6(50-60)$ \\
\hline & & & & \\
\hline & 60 & & \\
\hline
\end{tabular}




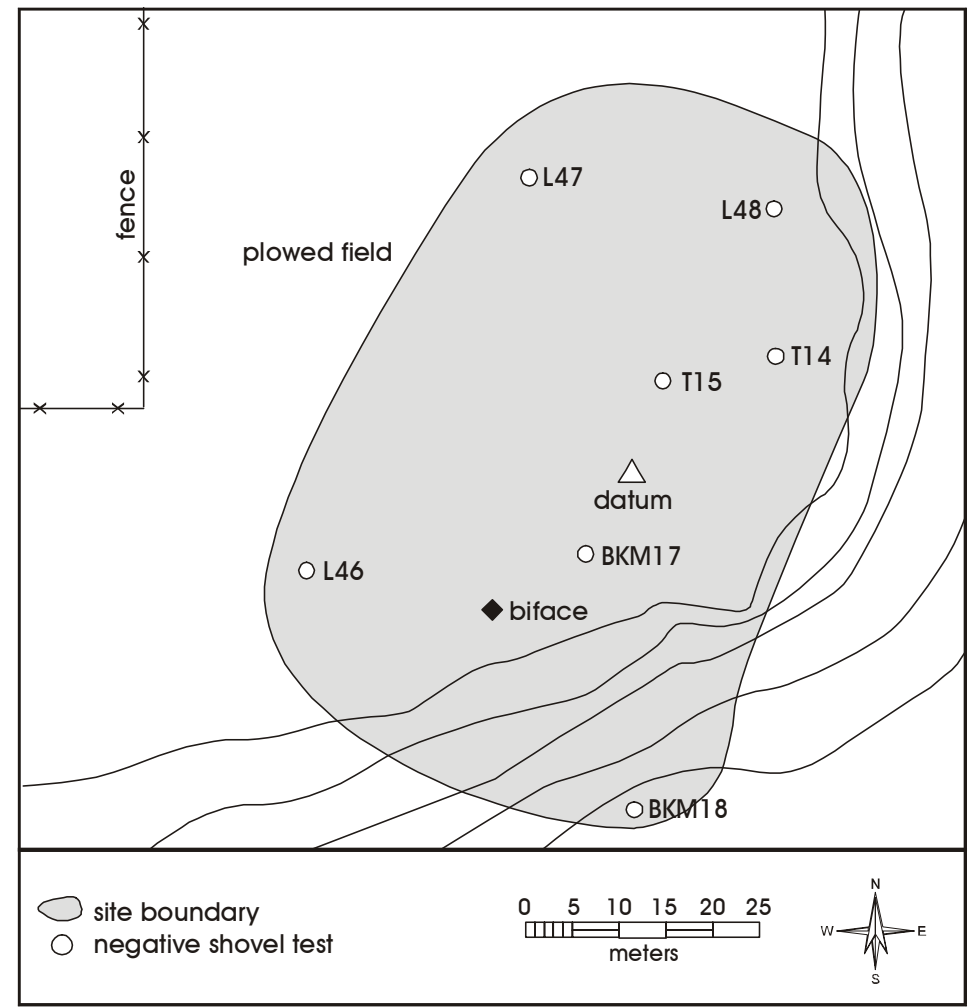

Figure 4-23. Site map of $41 B X 1580$.

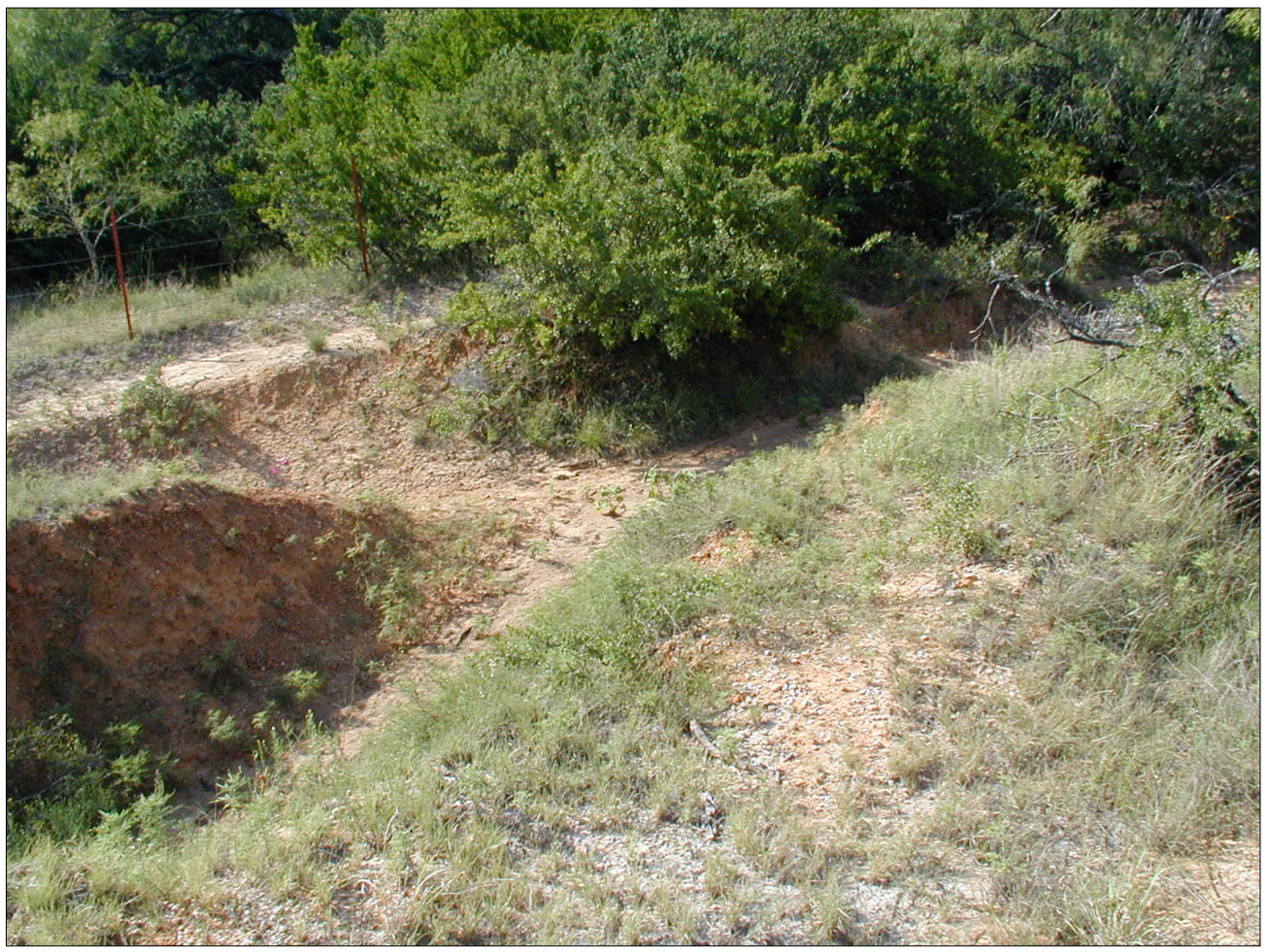

Figure 4-24. Photo of erosion at $41 B X 1580$. 
Archaeological Survey of the Proposed Medina River Park

\section{Chapter 5: Summary and Management Recommendations}

This chapter summarizes the findings of the CAR survey and provides National Register of Historic Places (NRHP) and State Archeological Landmark (SAL) eligibility recommendations for each site. In addition, it also makes specific management recommendations that are intended to address not only direct impacts to these sites resulting from park construction but also the indirect impacts of public use on the historic and prehistoric resources of the proposed park. Table 5-1 presents the summary of site characteristics, immediate park impacts, and recommendations derived from this fieldwork.

\section{Summary of Findings and Recommendations}

A 100 percent pedestrian survey was performed by CAR during July and August 2003. During the survey, CAR revisited and reassessed the NRHP and SAL eligibility of eight previously recorded archaeological sites within the proposed Medina River Park: 41BX346 (A \& B), 41BX347, 41BX348, 41BX350, 41BX519, 41BX675, 41BX837, and 41BX857. Four newly documented sites were also identified during fieldwork: 41BX1577, 41BX1578, 41BX1579, and 41BX1580.

Site 41BX346 is a multicomponent site with sparse historic and prehistoric materials present on surface. Buried prehistoric materials were encountered in only two of seven shovel tests excavated on site and none of the four backhoe trenches revealed materials and/or features. Mechanical disturbances to the site, associated with the demolition of a structure, have severely impacted the surface and shallow subsurface deposits. It is recommended that the site is not eligible for NRHP listing nor for SAL designation and no further work is recommended at the site. The site will be impacted by the construction of a parking lot and associated facilities.

Site 41BX347 was originally recorded as a multicomponent site with historic and prehistoric materials. No surface manifestations of the prehistoric materials were encountered and none of the seven shovel tests dug on site revealed prehistoric materials. The historic component is represented by a standing structure that may date as early as the 1940s. A second structure on the site dates to the early 1950s. Substantial renovations and additions to the earlier building have severely impacted its integrity and it is recommended that the site is not eligible for NRHP listing nor for SAL designation. No further work is recommended at the site. A portion of the planned hike and bike trail will cross the southern half of the site. The Medina River Park Master Plan (Carter \& Burgess 2002:28) indicates that such structures would likely be demolished since they represent a health and safety hazard for future patrons of the park.

Site 41BX348 is a prehistoric site with sparse surface artifacts and few buried prehistoric lithics that are likely in secondary context. Only one of the 11 shovel tests recovered buried materials; artifacts came from Levels 1 and 4 . The surface of the site is subject to heavy erosion that appears to have removed much of the cultural material noted on surface during the original recording of the site. The site has minimal research potential and it is recommended that this site is not eligible for NRHP listing nor for SAL designation. No further work is recommended at this site. The site is located some 250 meters east of the nearest trail segment.

41BX350 is a heavily eroded prehistoric site with only one artifact noted on surface during survey. The six shovel tests excavated on site were negative and the site has minimal research potential. It is recommended that the site is not eligible for NRHP listing nor for SAL designation and no further work is proposed at this site. The nearest trail passes some 500 meters west of the site.

Site 41BX519 was originally defined as a historic site. The current CAR survey identified a prehistoric component along the southern portion of the site with historic materials extending into this area. Therefore, the site is redefined as a multicomponent site with historic and prehistoric components. The cultural materials occur in moderate to high density across the site providing high surface visibility. Two of the nine shovel tests dug on site revealed historic artifacts but no buried prehistoric materials. Given the disturbed nature of the historic component and the surface character of the prehistoric debris, the site has low research potential and is not 


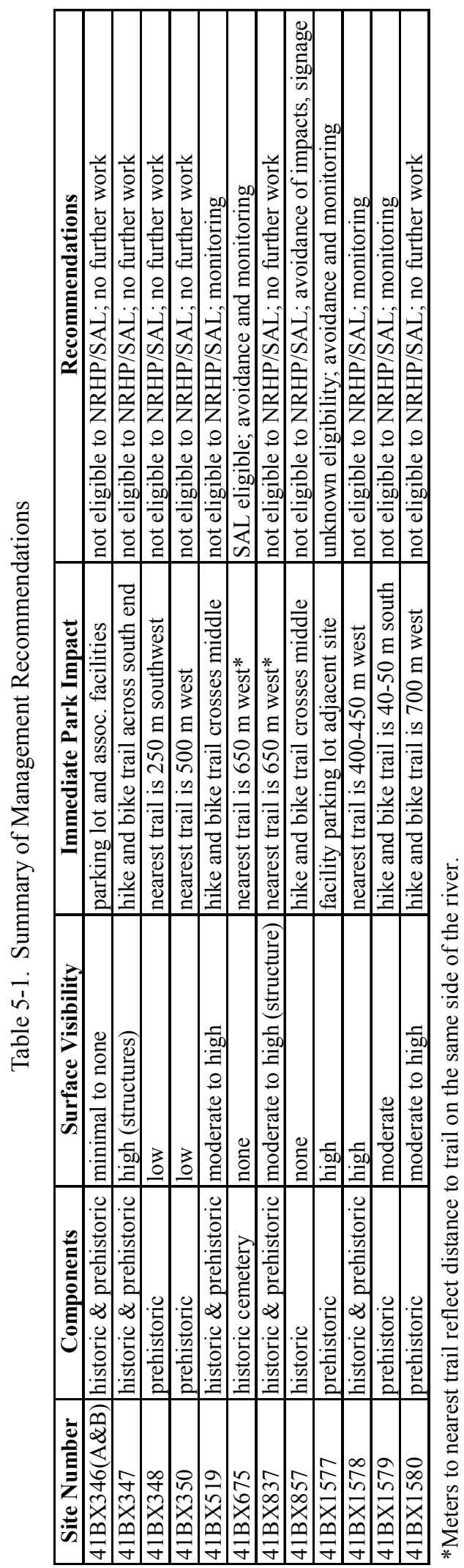

recommended for nomination to the NRHP nor for designation as a SAL. However, given that a park trail is planned across the center of the site, monitoring of the effect of park use on surface artifact distributions is recommended.

Site 41BX675 is the location of the historic Thompson (Jett) Cemetery. Although the iron fence and grave markers that were present at one time are missing, the site is eligible for SAL designation and avoidance of any impacts to the locality are recommended. As presently drawn, a 30-meter diameter buffer zone is suggested around the presumed actual location of the cemetery. Furthermore, it is recommended that the site be systematically monitored to prevent the destruction of the cemetery by active erosion of the floodplain.

41BX837 is a multicomponent site with sparse historic and prehistoric artifacts evident on surface within the portion of the site located inside the proposed park boundary. Five shovel tests were excavated within the portion of the site found inside the park. No prehistoric materials were identified in the shovel tests but a single historic metal artifact was recovered. The post-1950s structures that stood on the property during the original recording of the site are no longer present. Due to heavy disturbance and the low density of materials, the site has minimal research potential. It is recommended that the site is not eligible for nomination to the NRHP nor for designation as a SAL, therefore, no additional work is proposed at this site.

Site 41BX857 is the location of the historic Palo Alto Crossing of the Medina River. Severe erosion of the banks of the river in this locality has removed all cultural material indicators of the site that were noted on surface during the original recording. Therefore, based on the absence of material remains, it is recommended that the site is not eligible for nomination to the NRHP nor for SAL designation. Nonetheless, given the historic significance of the locality, the crossing as a landform still possesses historic significance. As a result, it is recommended that major intrusive disturbances to the locality be avoided to retain the physical authenticity of the site. In addition, it is recommended that signage be erected in the vicinity identifying the historical significance of the crossing. The segment of the hike and bike trail that is planned on the site will follow an existing dirt road. 
Site 41BX1577 is one of four newly documented sites within the proposed park. The site is located in a plowed field and the high density of surface artifacts provides high site visibility. Arrow point preforms and prehistoric pottery fragments suggest a Late Prehistoric Toyah Phase component. Presence of buried intact cultural materials and features is suggested below the plow zone. The work conducted by CAR was not sufficient to determine the NRHP/SAL eligibility of the site and it is recommended that Phase II testing be conducted if future park developments will impact the site. This archaeological work should be geared toward the definition of the site's NRHP/SAL eligibility. In the meantime, avoidance of disturbances and monitoring of the locality are proposed. No direct impact by park facilities construction will occur on the site, but its boundaries will abut the proposed parking lot in the northwest corner of the park.

41BX1578 is a multicomponent site with abundant highly visible historic and prehistoric artifacts on the current ground surface. Plowing of the site's surface has severely impacted cultural materials to a depth of $30 \mathrm{~cm}$ and the cultural materials appear to be contained entirely within the plow zone. Given the extreme degree of disturbance, it is recommended that the site is not eligible for NRHP listing nor for SAL designation. However, because of the high surface visibility of the cultural materials, it is recommended that the site be monitored to gauge the effect of public use upon the exposed artifacts. The site is located approximately 425 meters east of the nearest trail segment.

Site 41BX1579 is a prehistoric site with a moderate quantity of materials present on surface. The surface of the site has been impacted by animal wallows to a depth of approximately $20-30 \mathrm{~cm}$. Fourteen shovel tests were excavated on site, with nine recovering cultural materials. While the deposits range to a depth of $60 \mathrm{~cm}$, the majority of the artifacts were found in the upper $30 \mathrm{~cm}$. Because of the heavy disturbance of this zone, it is recommended that the site has minimal research potential and is not eligible for nomination for NRHP listing nor for designation as a SAL. Nonetheless, the high surface visibility of the deposits affords an opportunity to monitor the impact of public access to the park on surface artifacts. Therefore, monitoring of the site and its deposits are recommended as a long-term management strategy especially since the proposed trail will pass within roughly 45 meters of the site.
Site 41BX1580 is the fourth newly documented site within the proposed park. While prehistoric artifacts are abundant on the surface, the southern and eastern portions of the site are heavily eroded and cultural material is being washed into the adjacent gullies. Seven shovel tests were excavated at the site with none of them encountering buried materials. Although cultural materials are common on the surface, the lack of subsurface deposits and the likely secondary depositional context of many of the surface artifacts limits the research potential of the site. Therefore, CAR recommends that the site is not eligible for nomination for NRHP listing nor for SAL designation and we recommend no further work at the site. The nearest trail segment will be located some 700 meters west of the site.

\section{Suggested Archaeological Properties Management Strategies}

The archaeological sites found within the boundaries of the proposed park will undergo two types of impact, direct impact from construction of park facilities and features and indirect impact from public collecting of materials within the park. In addition, it has already been shown that the sites and their materials also are subject to erosion and other geomorphological processes that are at work in the project area. We propose a possible strategy to deal with direct impact to archaeological properties crossed by trail segments. In addition, we also propose a long-term monitoring strategy to gauge the indirect impact of park use upon the archaeological sites present in the park.

\section{Mitigation of Trail Impacts}

It was mentioned earlier that four archaeological sites will be directly impacted by park development: 41BX346, 41BX347, 41BX519, and 41BX857. While a parking lot will be built on top of a portion of 41BX346, trail segments will cross the other three sites. We propose that a 100 percent collection of all artifacts, with the exception of fire-cracked rock, be performed along selected portions of the proposed hike and bike trail rightof-ways crossing each of the three sites. These collections would mitigate the impacts of future collection and could also serve as educational materials that may be used in exhibits and other public outreach contexts associated with the development of the park. The surface collection 
sample would consist of individual 1-x-4-meter units centered on the trail(s). The actual number of collection units would depend on the length of trail(s) crossing the site. The minimum size of the artifacts collected would be $10 \mathrm{~mm}$ in maximum dimension. This size closely approximates the smallest sized artifacts consistently recovered in $1 / 4$-inch hardware cloth.

This strategy has two advantages. First, the strategy is focused on portions of the sites that have the highest probability of being directly impacted by visitors to the park. Second, it will be the most cost-effective strategy to mitigate future impacts.

\section{Mitigation of Collecting and Erosion on Site Surfaces and Assemblages}

Although it is commonly assumed that surface exposed archaeological sites will be impacted by collection and erosion, the nature of the impacts is not well documented and understood. For example, it is commonly assumed that formal tools are more likely to be collected than debitage, that larger items are more likely to be collected than smaller items, that the rate and intensity of surface collection is a function of the number of individuals using a specific area, and that slopes dramatically impact artifact movement. However, little or no actual quantitative data exist in support of most of these assumptions. In this section, we propose a strategy to begin to develop quantitative data on the actual impacts associated with opening facilities such as Medina River Park for public use. While Medina River Park will be open long before these data are available, and therefore they cannot be used in the decision-making process regarding surface collection strategies implemented for the current project, the information can be used to assess both the effectiveness of the mitigation strategy chosen and provide guidance for other Parks and Recreation Department properties.

In the previous summary and recommendations section, we recommended monitoring of archaeological assemblages on five archaeological sites: 41BX519, 41BX675, 41BX1577, 41BX1578, and 41BX1579. Site 41BX675 is the cemetery with no surface indication, and the monitoring would be implemented to prevent total site erosion and the potential loss of graves. Of the remaining four sites, two are near (less than 50 meters) proposed trails (41BX1577 and 41BX1579), one is crossed by a trail (41BX519), and one is at some distance $(425 \mathrm{~m})$ from a trail (41BX1578). The combination of sites crossed by trails, not crossed by but near trails, and far from trails provides opportunities to gauge, among other things, the impact of site distance from trails upon collecting behavior. The different land forms, and variability in vegetation cover between sites also provides opportunities to observe the impact of erosion of site assemblages.

To obtain data on collecting and erosion impact to archaeological assemblages, we suggest that a series of one to three observation units be positioned on each of these sites. These observational units would be 5-x-5meter squares. We suggest that within each site, the observation units be positioned at different distances (e.g., 5, 15, and 25 meters) from the trails and that, when possible, a variety of different slopes should be selected for the units. We suggest that an inventory of all surface artifacts should be made for each unit. The inventory should minimally identify the artifact types, including unmodified flakes, the maximum size of the artifact, and the weight of the specimen. We propose that each artifact within each specific control unit also should be photographed. The artifacts would then be placed on the ground and their precise location recorded with an EDM. While the control units should not be marked, a nearby datum should be set up to allow the precise mapping of all artifacts. This information will provide a baseline for monitoring the impacts of collection on both the content of artifacts at increasing distances from the trails, as well as the impact of slopes and trail use on artifact movement.

Personnel should relocate and inventory these control units at some consistent temporal interval (e.g., every six months). These semi-annual inventories will provide information on the rates of artifact movement and collection and identify the types of artifacts most likely to be collected from the park. Information from the different control units located at increasing distances from the trails and in off-trail artifact concentrations will, in combination with data on the number of park visitors, provide information on the distance away from the trails that visitor impact may be expected. In conjunction with this information, the point-plotted artifact locations will provide data on the degree and scale of artifact displacement due to erosion and foot 
traffic. These data may be useful in estimating the scale of artifact displacement and associational integrity of material. At a larger scale, the data generated from this monitoring strategy would allow managers to begin to quantify both the impact of public access on assemblages as well as aspects of erosion on archaeological resources. Aspects of these data should be applicable to other Parks and Recreation Department properties, as well as useful for other agencies in the state. 


\section{References Cited}

Black, S. L.

1986 Clemente and Herminia Hinojosa Site, 41JW8: A Toyah Horizon Campsite in Southern Texas. Special Report No. 18. Center for Archaeological Research, The University of Texas at San Antonio.

1989 Central Texas Plateau Prairie. In From the Gulf Coast to the Rio Grande: Human Adaptation in Central, South and Lower Pecos Texas, by T. R. Hester, S. L. Black, D. G. Steele, B. W. Olive, A. A. Fox, K. J. Reinhard and L. C. Bement, pp. 17-38. Research Series No. 33. Arkansas Archaeological Survey, Fayetteville.

Black, S. L., and A. J. McGraw

1985 The Panther Springs Creek Site: Cultural Change and Continuity in the Upper Salado Creek Drainage, South-Central Texas. Archaeological Survey Report, No. 100. Center for Archaeological Research, The University of Texas at San Antonio.

Bomar, G. W.

1995 Texas Weather. University of Texas Press, Austin

Carter \& Burgess, Inc.

2002 Medina River Park Master Plan. Prepared for the City of San Antonio. Manuscript on file Center for Archaeological Research, The University of Texas at San Antonio.

Collins, M. B.

1995 Forty Years of Archeology in Central Texas. Bulletin of the Texas Archeological Society 66:361-400.

Hester, T. R.

1995 The Prehistory of South Texas. Bulletin of the Texas Archeological Society 66:427-459.

Hindes, $\mathrm{K}$.

2003 Historic Roads and River Crossings in the Lower Medina River Valley. In Historic Archaeological Investigations in the Applewhite Reservoir Project Area, Bexar County, Texas, edited by M. M. Green, R. W. Moir, and K. Hindes, pp. 27-49. Reports of Investigations No. 6. Center for Ecological Archaeology, Texas A\&M University, College Station, Texas.

McGraw, A. J., and K. Hindes

1987 Chipped Stone and Adobe: A Cultural Assessment of the Proposed Applewhite Reservoir, Bexar County, Texas. Archaeological Survey Report, No. 163. Center of Archaeological Research, The University of Texas at San Antonio.

Prewitt, E. R.

1981 Culture Chronology in Central Texas. Bulletin of the Texas Archeological Society 52:65-89.

Taylor, F. B., R. B. Hailey, and D. L. Richmond

1991 Soil Survey of Bexar County, Texas. Soil Conversation, U.S. Department of Agriculture, Washington D.C. 
Texas Historical Commission (THC)

2003 Texas Archeological Sites Atlas. <http://pedernales.thc.state.tx.us/>

Thoms, A. V., D. D., Kuehn, B. W. Olive, J. E. Dockall, P. A. Clabaugh, and R. D. Mandel

1996 Early and Middle Holocene Occupations at the Richard Beene Site: The 1995 Southern Texas Archaeological Association Field School Project. La Tierra 23(4):8-36.

Vines, R. A.

1960 Trees, Shrubs and Woody Vines of the Southwest. University of Texas Press, Austin. 
